\title{
Growth factors and management technique used in relation to the developmental rhythm and yield formation pattern of a pure grass stand
}

\author{
Seppo Pulli \\ University of Helsinki, Department of Plant Husbandry, 00710, Helsinki 71
}

\begin{abstract}
The investigation of meadow fescue as a forage crop was carried out at the University of Helsinki in Viikki in 1975-78. The main objective was to study the rhythm of the growth and yield formation pattern of a stand and the relationship between growth pattern and growth factors during different phases of the growing season. The management techniques studied were the number of cuttings, use of nitrogen, requirements of population density and the relationships of management factors to the changes in the quantity and quality of forage yield.

The most important growth factors in the seeding year spring and autumn development were the temperature sum and the total radiation available to the plant and nitrogen fertilization beyond the temperature sum range of $\Sigma 500^{\circ} \mathrm{C}$, respectively.

During the production years the most important variables in the spring growth were the growing time, the temperature sum and the total radiation. The midsummer and autumn growth were mostly influenced by the total precipitation, amount of nitrogen for the cut and the precipitation during the week before the prior cut.

For spring, summer and autumn growth one unit increase in LAI created a DM yield increase of 715,500 and $315 \mathrm{ha}^{-1}$ respectively.

Increasing the cutting frequency from two to four decreased the total DM yield $2527 \mathrm{~kg} \mathrm{ha}^{-1}$. The protein content and DM cellulase digestibility increased 4.8 and $13.3 \%$ units respectively. Increasing nitrogen from 130 to $260 \mathrm{~kg} \mathrm{~N} \mathrm{ha}^{-1}$ raised DM and protein yields 1110 and $485 \mathrm{~kg} \mathrm{ha}^{-1}$, the protein content and DM cellulase digestibility 4.2 and $1.4 \%$ units. The seeding rate requirements for the maximum DM yield were $60 \mathrm{~kg} \mathrm{ha}^{-1}$ in the seeding year, $15-30 \mathrm{~kg} \mathrm{ha}^{-1}$ in the second year and $15 \mathrm{~kg} \mathrm{ha}^{-1}$ in the third year.

The management system involving a seed rate of $30 \mathrm{~kg} \mathrm{ha}^{-1}, 3-4$ cuts and $260 \mathrm{~kg}$ $\mathrm{N} \mathrm{ha-1}$ is recommended.
\end{abstract}

\section{Introduction}

The growth and development of a forage crop follows a S-shaped growth pattern. The shape of the growth curve is defined by the growth factors, the management technique used and the utilization of the crop. A plant's growth and development are dependent on the environmental factors surrounding the crop. Of these factors, the most important are the growth 
medium's characteristics, the amount of light, temperature, the amount of available water and the availability of nutrients. The most effective utilization of the feeding material in order to meet economic constraints and forage feeding standard requirements is achieved through proper management techniques. It is important to know the quantity and quality changes connected to the plant's stage of development. These factors, combined with the intended use of the forage, determine its cutting schedule. Although many previous investigators (Huokuna 1964, Raininko 1968, Poutiainen and Rinne 1971, SyrJälä 1973-78, Salo et al. 1975, Rinne 1977, Hakkola 1978) have fundamentally described the relationships between growth stage and the cuttings schedule, the relationships between growth stage and growth factors demand more investigation. In addition, while energy prices continue to rise, the quantity of the nitrogen fertilizer and the time of its application during the growing season are becoming increasingly more important factors affecting the economic gains of forage production.

When establishing a stand without a companion crop, and the stand will be harvested in the year of seeding, the seeding rate needs to be taken into consideration, even more so than when using a companion crop. The observation is supported by the fact that since the studies during the 1940's and 1950's (Pohjakallio 1941, Salonen 1951, PaAtela 1953, Laine 1955 and 1958) relatively few studies have been conducted in Finland dealing with seeding rates and crop establishment techniques related to the population density.

In this investigation the primary aim was to study the effects of cutting frequency, nitrogen fertilization and seed rates on the growth, development and yield formation of a forage stand. The investigation's second objective was to study the relationships between the crop's development and harvest rhythm and their relationships to the growth factors at different phases throughout the growing season. The growth analysis studies by the means of regression models has first used in Finland by BRUMMER (1961). The investigations were conducted in $1975-78$.

\section{Material and methods}

\section{Experimental design}

The field trials were established on the Helsinki University farm in Viikki in 1975. The plots were organized in the following ways:

Experimental design: Split-plot

Main plot:

Cutting treatments

1. 2-cut

2. 3-cut

3. 4-cut

Sub-plot:

Nitrogen fertilization

1. $130 \mathrm{~kg} \mathrm{~N} \mathrm{ha-1}$

2. $260 \mathrm{~kg} \mathrm{~N} \mathrm{ha-1}$ 
The plots were established on an eastward facing slope. The soil type was fine sand and the variety was Tammisto meadow fescue.

\section{Fertilization and plant protection}

In the spring of the seeding year the basic amount of commercial fertilizer mixture was $675 \mathrm{~kg} \mathrm{ha}^{-1}$ NPK $(15-25-15)$, which represents $100 \mathrm{~kg} \mathrm{~N} \mathrm{ha-1.}$

After the first cut a higher nitrogen level was used. The 1975 nitrogen levels were:

$$
\begin{aligned}
& 100 \mathrm{~N}=100 \mathrm{~kg} \mathrm{~N} \mathrm{ha-1} \\
& 200 \mathrm{~N}=200 \mathrm{~kg} \mathrm{~N} \mathrm{ha}^{-1}
\end{aligned}
$$

In the spring of 1976 and 1977 the basic application of commercial fertilizer mixture was $1000 \mathrm{~kg} \mathrm{PK} \mathrm{ha-1}(2-15-15)$. The amount of nitrogen per cut was applied as follows $(\mathrm{Nos}=27-0-0)$

2-cut system:

$130 \mathrm{~N}$

In spring

After 1st cut

3-cut system:

In spring

After 1st, 2nd cuts

4-cut system:

In spring

After 1st, 2nd, 3rd cuts

\section{$200 \mathrm{~kg}$ Nos ha-1}

$200 \mathrm{~kg}$ Nos ha-1

$\frac{130 \mathrm{~N}}{100 \mathrm{~kg} \text { Nos ha-1 }}$

$150 \mathrm{~kg}$ Nos ha-1

$130 \mathrm{~N}$

$100 \mathrm{~kg}$ Nos ha-1

$100 \mathrm{~kg}$ Nos ha-1
$260 \mathrm{~N}$

$435 \mathrm{~kg}$ Nos ha-1

$435 \mathrm{~kg}$ Nos ha-1

\section{$260 \mathrm{~N}$}

$270 \mathrm{~kg}$ Nos ha-1

$300 \mathrm{~kg}$ Nos ha-1

$260 \mathrm{~N}$

$220 \mathrm{~kg}$ Nos ha-1

$220 \mathrm{~kg}$ Nos ha-1

To study the management effects in 1978 all of the treatments received $500 \mathrm{~kg} \mathrm{ha}^{-1}(15-15$ -15) which represented $75 \mathrm{~kg} \mathrm{~N} \mathrm{ha}^{-1}$. A herbicide (dinoseb, $1.6 \mathrm{~kg} \mathrm{ha}^{-1}$ ) was applied to control broadleaf weeds and a watering schedule of $4 \times 30 \mathrm{~mm}$ was followed to ensure germination after seeding.

Cutting and yield procedure

During the seeding year the plots were cut twice:

First cut -8 August

Second cut -29 September.

For the actual production years $1976-77$ the cutting schedule was as follows:

2-cut system:

$\begin{array}{lll} & \frac{1976}{2} \text { July } & \frac{1977}{27} \text { June } \\ \text { 2nd cut } & 27 \text { September } & 27 \text { September }\end{array}$

3-cut system:

$\begin{array}{lll}\text { 1st cut } & 18 \text { June } & 13 \text { June } \\ \text { 2nd cut } & 27 \text { July } & 28 \text { July } \\ \text { 3rd cut } & 27 \text { September } & 27 \text { September }\end{array}$

4-cut system:

$\begin{array}{lrl}\text { 1st cut } & 4 \text { June } & 2 \text { June } \\ \text { 2nd cut } & 8 \text { July } & 6 \text { July } \\ \text { 3rd cut } & 10 \text { August } & 18 \text { August } \\ \text { 4th cut } & 27 \text { September } & 27 \text { September }\end{array}$


In order to investigate the management post effects the stand was harvested on 19 June 1978.

Two $200 \mathrm{~g}$ samples of chopped forage material were taken and dried for $24-36 \mathrm{~h}$ at $100^{\circ} \mathrm{C}$. The raw protein and digestibility samples were taken and dried for $24-36 \mathrm{~h}$ at $70^{\circ} \mathrm{C}$.

The raw protein content of the dried and ground samples was determined according to the Kjeldahl method. For determining the digestibility of DM, the one-stage chemical method of Jones and Hayward (1973) was employed (Pulli 1976).

Crop growth and yield analyses

The leaf area index (LAI) and the overall height of the crop were measured weekly during the seeding year throughout the growing season. In 1976-77 both the LAI and height of the crop were determined weekly in the spring and in the summer and fall cuttings.

Leaf area was measured with leaf planimeter, an optical instrument model $\mathbf{K}_{1}$ designed and built by the Technical university of Helsinki.

During 1976 the raw protein content and the cellulase digestibility of dry matter were measured weekly throughout the spring, summer and autumn. In 1977 over the same time period also the development of the dry matter content was recorded in addition to the raw protein and digestibility factors.

\section{Weather conditions}

The average temperatures and amount of precipitation for $1975-77$ and the long term average are presented in Table 1 . The temperature sum in degree days $\left(\Sigma>0^{\circ} \mathrm{C}\right)$ and the total amount of solar radiation $\left(\Sigma \mathrm{Wh} \mathrm{cm}^{-2}\right)$ from the seeding day in 1975 and from the beginning of the 1976-77 growing season to the last cutting day are shown in Fig. 1. The meteorological data was obtained from the Malmi airport station $1.5 \mathrm{~km}$ from the experimental fields. On the average, summer 1975 was warmer and drier than the long-term average. The mean temperature of June fell slightly below the long-term average and precipitation was exceptionally low from June to August.

Table 1. Average temperatures $\left({ }^{\circ} \mathrm{C}\right)$ and precipitation $(\mathrm{mm})$ May-Sept. in $1975-77$ at Malmi airport.

\begin{tabular}{lrrrrrrrr}
\hline \multirow{2}{*}{ Month } & \multicolumn{3}{c}{ Temperature ${ }^{\circ} \mathrm{C}$} & \multicolumn{3}{c}{ Precipitation mm } \\
& 1975 & 1976 & 1977 & $1931-60$ & 1975 & 1976 & 1977 & $1931-60$ \\
\hline May & 11.7 & 10.7 & 9.4 & 8.4 & 38 & 27 & 22 & 41 \\
June & 13.7 & 13.0 & 14.4 & 14.1 & 12 & 42 & 36 & 47 \\
July & 18.0 & 15.9 & 14.7 & 17.2 & 26 & 52 & 122 & 68 \\
Aug. & 16.6 & 15.2 & 14.5 & 15.6 & 29 & 45 & 47 & 70 \\
Sept. & 13.3 & 8.1 & 8.3 & 10.5 & 53 & 48 & 73 & 66 \\
\hline Avg & 14.7 & 12.6 & 12.3 & 13.2 & $\Sigma 158$ & 214 & 300 & 292 \\
\hline
\end{tabular}

In 1976, May was, on the average, warmer and less rainy. From June to the end of July the weather was cool and drier than the long-term average. The rains in August were concentrated in the beginning of the month. September was cool. The radiation energy conditions were comparable to those for $\mathbf{1 9 7 5 .}$ 
The 1977 growing season wound up being cooler than the long-term average. The greatest negative deviation from the average occurred in July, September was even cooler than in 1976. May, June and August were, under the conditions, somewhat drier, but July was very wet and September matched the long-term average. In 1977 the total radiation decidedly fell below the 1975-76 sum especially in July, which was exceptionally cloudy and rainy.

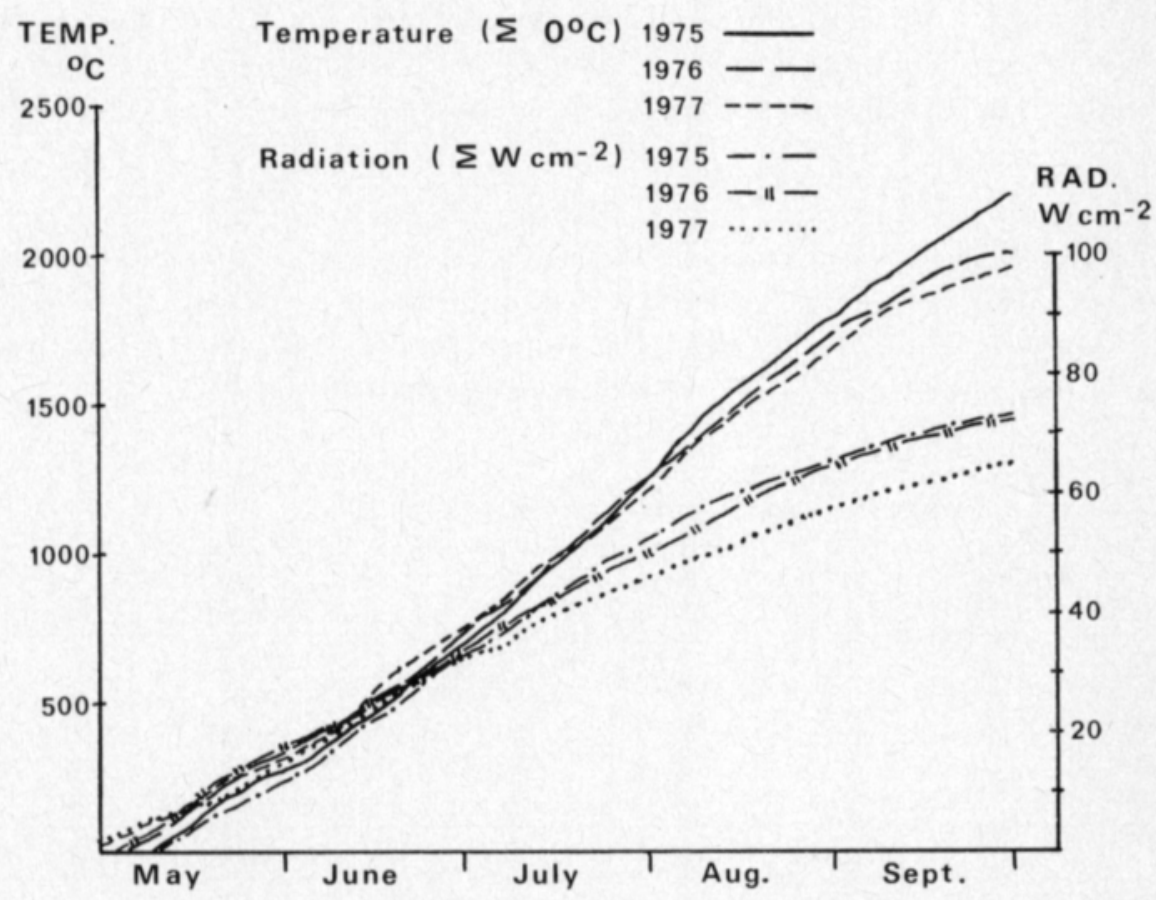

Fig. 1. Total amount of radiation $\left(\Sigma \mathrm{Wh} \mathrm{cm}^{-2}\right)$ and temperature in degree days $\left(\Sigma>0^{\circ} \mathrm{C}\right)$ in the experimental area during $1975-77$.

\section{Results and discussion}

\section{1. Development and Growth of Seeding Year Stand}

\section{1. 1. Population density}

Numerous investigations have shown that an individual plant's development is not affected by the stand density as long as the plant's space requirements are met. As soon as the space limit is reached and exceeded, then the interplant competition, by reducing the rate of plant growth, brings about a smaller plant size. The reduction in growth rate occurs earlier and more strongly the denser the stand is (Donald 1951 and 1963, Baeumer 1964, Murtagh and Gross 1966). Increasing density reduces the amount of individual plants already in the germination stage (BRAun-BLAnQUet 1964, NorringtonDavies and Harries 1977), but even more so as the stand develops under 
particularly dense conditions. In a well spaced stand changes in the number of plants are few. However, over time the number of individuals associated with different population densities turn out to be the same because a perennial forage crop has the tendency, under prevailing competition and constant growing conditions, to gradually reach an adjusted population density (Donald 1951, HARPER and GaIJIC 1961). In addition to the intraspecific competition also, the management technique, crop's age and, especially under Finnish growing conditions, wintering affect the population density and the yield of the invidual plant. BAKER (1957) and BAKER and GARWOOD (1959) oberved in a stand that was cut frequently a considerably larger amount of individuals at the end of the growing season than in a nonmowed stand.

\section{Results}

The established stand emerged 12 days after seeding at all of the seeding densities. The first growing density measurements were taken three weeks after establishment (29 May) and the second set was taken on 3 July, eight weeks after establisment. The results are presented in Table 2.

Table 2. Stand density development in the seeding year in 1975 .

\begin{tabular}{|c|c|c|c|c|c|c|}
\hline \multicolumn{2}{|c|}{ Seeding rate } & \multicolumn{3}{|c|}{ Density June 10} & \multicolumn{2}{|c|}{ Density July 3} \\
\hline $\mathrm{Kg} \mathrm{ha}^{-1}$ & Seeds m-2 & & Plants $\mathrm{m}^{-2}$ & $\%$ & Plants $\mathrm{m}^{-2}$ & $\%$ \\
\hline 7.5 & 325 & & 109 & 33.5 & 202 & 62.2 \\
\hline 15 & 650 & & 207 & 31.9 & 239 & 37.8 \\
\hline 30 & 1300 & & 405 & 31.2 & 414 & 31.9 \\
\hline \multirow[t]{2}{*}{60} & 2600 & & 959 & 36.9 & 386 & 14.9 \\
\hline & & Avg. & 420 & 33.4 & 310 & 36.7 \\
\hline
\end{tabular}

Despite relatively good soil conditions emergence was only $33.4 \%$. At the time of emergence there were no significant differences in the percentages of emergence between densities. Severe competition factors developed in June and the stand with the greatest density experienced considerable thinning in July. The greatest plant density was achieved with the seeding rate of $30 \mathrm{~kg} \mathrm{ha}^{-1}$ The final emergence percentage dropped very sharply with increasing seeding rate (Table 2 ).

\section{1. 2. Development of LAI and plant height}

In a young forage stand the assimilated LAI is directly proportional to the population density. At the early stage of development the crop's growth is much more rapid under dense condititions than those of more space, resulting in the occurrence of an optimum LAI first in the dense stands (DAvidson and Donald 1958, Donald 1963).

Along with the seeding density the LAI is affected also by the number of shoots. According to Huokuna (1966) grass produces shoots more abundantly at low seeding rates rather than at high ones, but the differences in the number 
of shoots affecting yield level have major importance only during the three first months after seeding.

Under spaced conditions a crop in the early stages of development produces noticeably more leaves than under dense conditions (Thomas 1974). ScarisBRICK and IVINS (1970) point out that frequent cutting significantly reduces both the number of shoots and the number of leaves per shoot in all cuttings.

As the growing density increases the net assimilation rate (NAR) tends to decrease. If the competition for light is severe, the decrease is relatively rapid (Blackman 1968, Kvet et al. 1971). Nishimura and Nitta (1974) observed the net assimilation rate and cross growth rate (CGR) to be higher in well spaced stands than in dense ones, irregardless of similar LAI values.

With nitrogen fertilization it is possble to obtain the proper LAI optimal for high production and to maintain it (DONALD and BLACK 1958).

The effect of nitrogen on the leaf area has good duration throughout the entire growing season (WATson 1956). Phosphorus increses leaf area only in early stages of development and later, during ripening, it hastens the reduction of the LAI. Potassium, on the other hand, when applied in the later stages of growth is an effective agent for reducing the phosphorus influence (WATSON 1956).

The height increase of a forage crop follows a sigmoidal curve. In the early stages of development there are relatively little height growth and leaf size increases. During stem development height growth is the greatest. Maximum height is attained in the stage of flowering. Of the factors influencing height growth, temperature accounts for $75-96 \%$ of the result (HARI and LEIKoLA 1974). According to Mitchell (1956) the optimal temperature for leaf growth of a forage crop in cool areas is $18-21^{\circ} \mathrm{C}$, resulting in daily increases of $1-5$ $\mathrm{cm}$ for various grasses.

A reduction in the amount of light results in intense competition for light and height growth of the stand increases (HaN et al. 1977). Height growth will continue to increase until the light intensity reaches $50 \%$ of full daylight. Any further reduction in light intensity causes a reduction in height growth because the shading becomes too great (KAMEL 1959). This has a significant influence, particularly on fall plant growth (PoHJONEN and HARI 1973).

\section{Results}

For all seeding densities the initial increases in LAI and height growth were similar in the early stages of the seeding year. Only for the density of 325 seeds $\mathrm{m}^{-2}$ was the LAI constantly below the values by a slight amount (Fig. 2).

The early phase of the seeding year LAI and height growth were best described by the following regression equations (Fig. 3):

a) Growing days $=\mathrm{X}$

LAI: $\quad \mathrm{Y}=-1.0429+0.116769 \mathrm{X}-0.002755 \mathrm{X}^{2}+0.000024 \mathrm{X}^{3}\left(\mathrm{R}=.9923^{* * *}\right)$

$\mathrm{cm}: \quad \mathrm{Y}=-5.57404+0.501106 \mathrm{X}-0.00349 \mathrm{X}^{2}+0.000035 \mathrm{X}^{3}\left(\mathrm{R}=.9972^{* * *}\right)$

b) Temperature sum $\Sigma{ }^{\circ} \mathrm{C}=\mathrm{X}$

LAI: $\quad \mathrm{Y}=-0.444758+0.00325 \mathrm{X}-0.0000037 \mathrm{X}^{2}+0.0000000028 \mathrm{X}^{3}\left(\mathrm{R}=.9923^{* * *}\right)$

$\mathrm{cm}: \quad \mathrm{Y}=-6.51441+0.041844 \mathrm{X}-0.000019 \mathrm{X}^{2}+0.0000000078 \mathrm{X}^{3}\left(\mathrm{R}=.9967^{* * *}\right)$ 


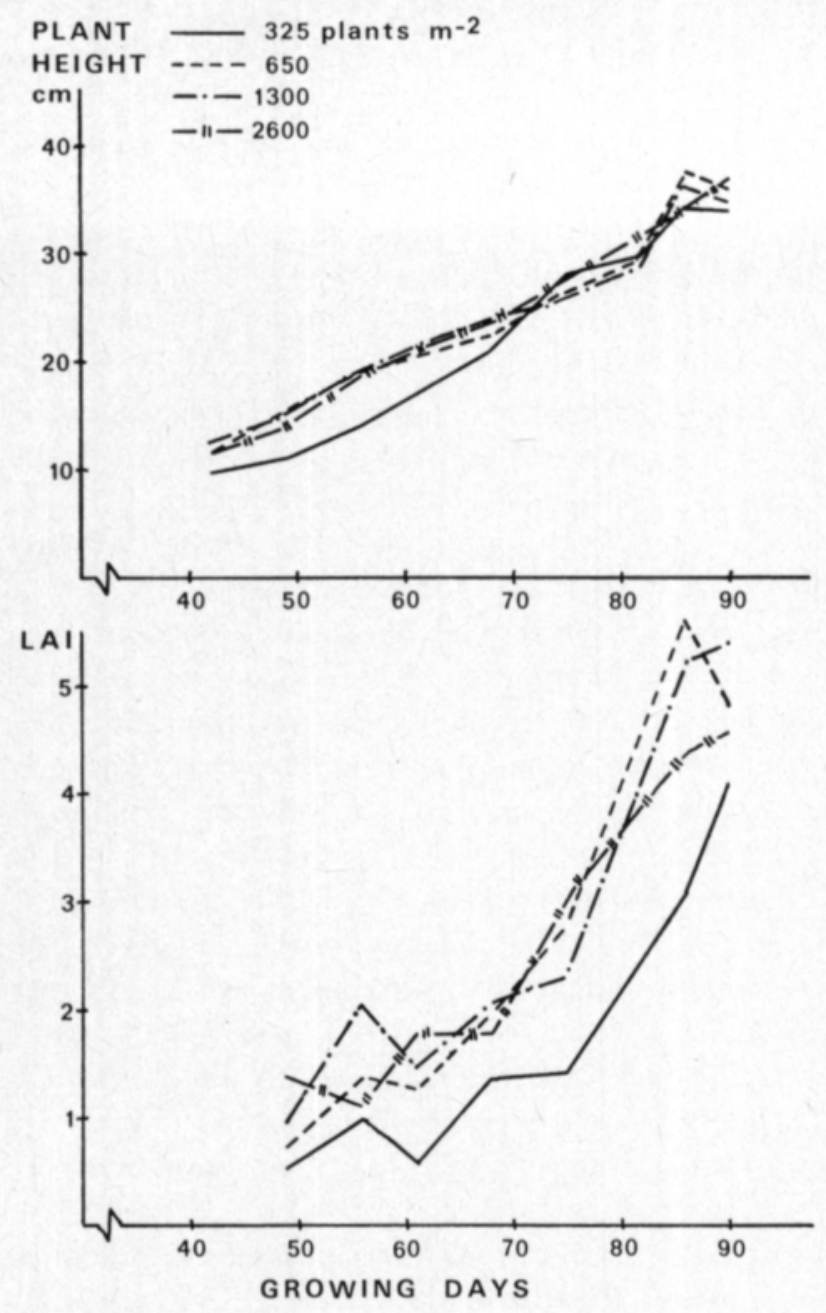

Fig. 2. Height and LAI development of the seeding year stand at four different population densities.

For the multiple regression analysis the variables of temperature sum in degree days $\left(\Sigma^{\circ} \mathrm{C}\right)$ and the total radiation sum $\left(\Sigma \mathrm{Whcm}^{-2}\right)$ clearly proved to be the most important ones for early development of the seeding year's LAI and height growth. Other growth factors had statistically significant correlations as well (Table 3 ). The regression equation of $\mathrm{Y}=0.33481+0.01744 \mathrm{X}_{1}-$ $0.35620 \mathrm{X}_{2}$ where $\mathrm{X}_{1}=\Sigma{ }^{\circ} \mathrm{C}$ and $\mathrm{X}_{2}=\Sigma \mathrm{Whcm}^{-2}$ accounted for $99.1 \%$

Table 3. The correlation coefficients between growth factors and LAI and plant height in the seeding year development of the stand.

\begin{tabular}{lll}
\hline Factors & LAI & Height \\
\hline Growing time & $.959^{* * *}$ & $.993^{* * *}$ \\
$\Sigma>0^{\circ} \mathrm{C}$ (temp.) & $.965^{* * *}$ & $.993^{* * *}$ \\
$\Sigma \mathrm{Whcm}^{-2}$ (rad.) & $.934^{* *}$ & $.982^{* * *}$ \\
$\Sigma \mathrm{mm}$ (prec.) & $.868^{*}$ & $.928^{* *}$ \\
\hline
\end{tabular}



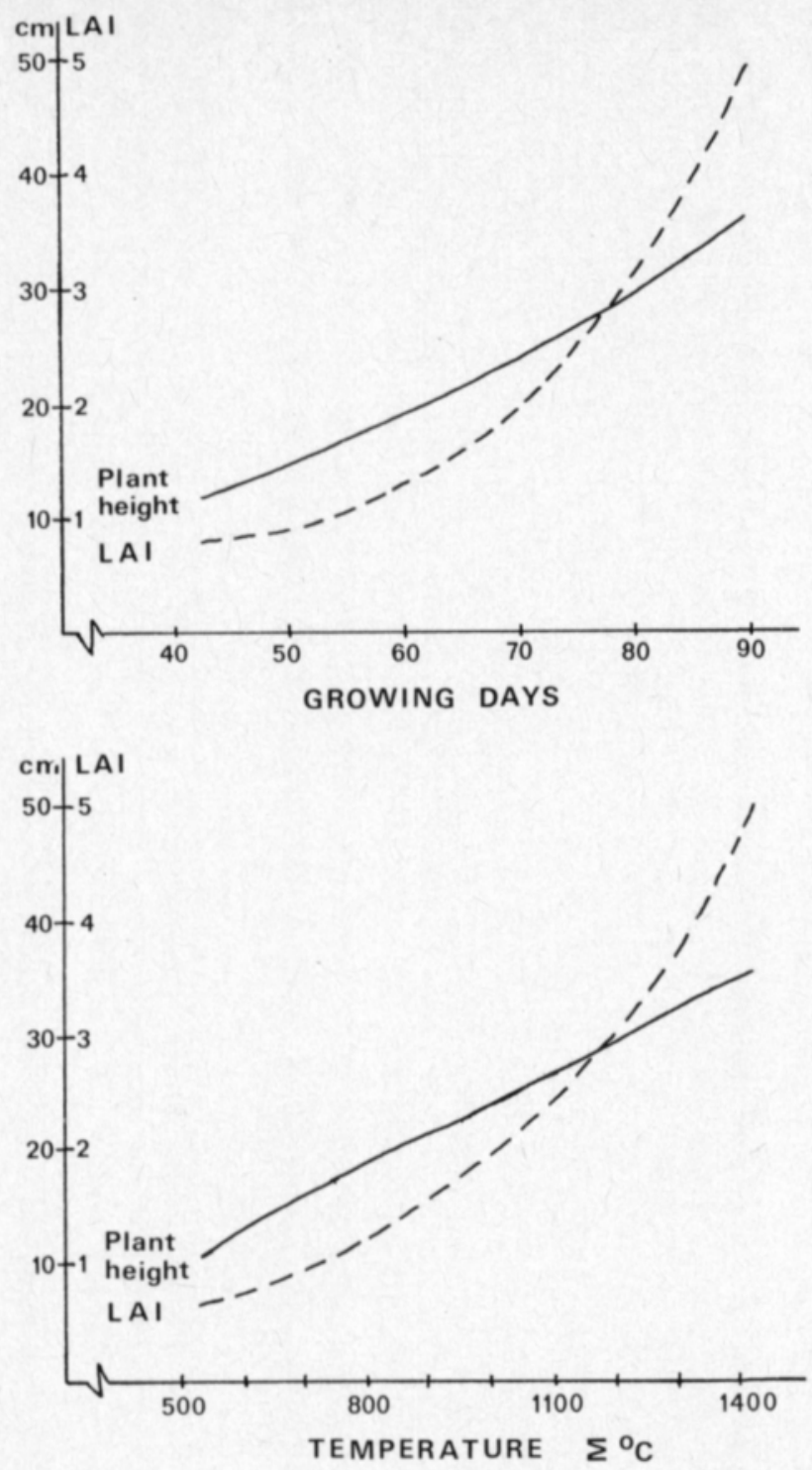

Fig 3. The relationship of plant height and LAI development to the growing time and to the temperature in degree days in the seeding year early growth.

$\left(\mathrm{F}\right.$-value $\left.=224.8^{* * *}\right)$ of the LAI increase. For height growth, temperature accounted for $98.5 \%$ (F-value $\left.338.5^{* * *}\right)$, no other factors fit into the regression model. The seeding year's height growth regression equation was $\mathrm{Y}=-$ $0.40726+0.00281 \mathrm{X}$.

After the first cutting of the seeding year the autumn growth model changed noticeably. LAI correlated very weakly to growing days or temperature sum. In addition, nitrogen fertilizer influenced the height growth.

The dependence of crop height on growing time or temperature sum followed the following regression equations for $100 \mathrm{~kg}$ and $200 \mathrm{~kg}$ annual nitrogen levels (Fig. 4): 

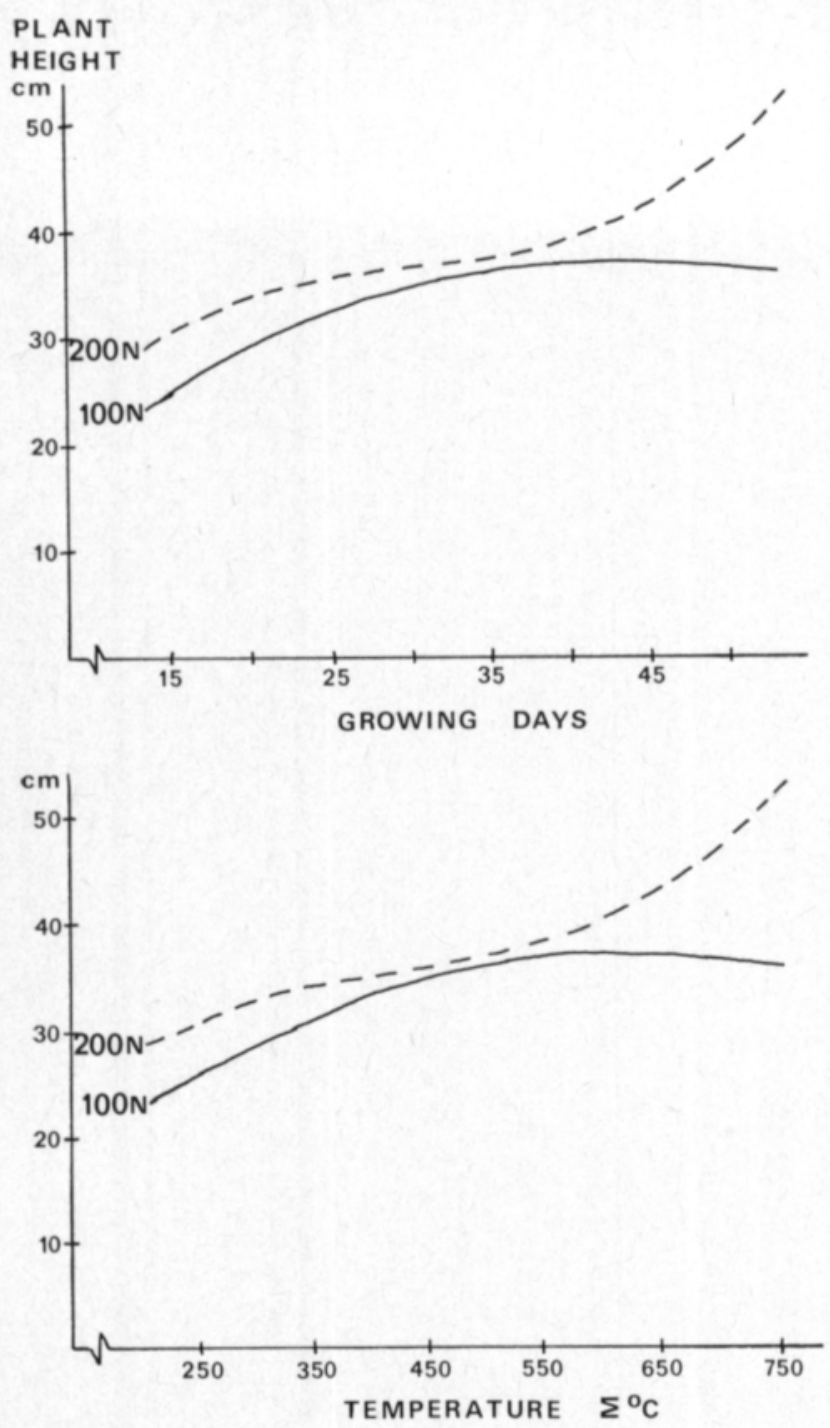

Fig. 4. The relationship of plant height development to the growing days and to the temperature conditions in degree days at two nitrogen levels in the fall growth after the first cut in the seeding year.

a) Growing days $=\mathrm{X}$

$100 \mathrm{~N}: \mathrm{Y}=5.08354+1.76477 \mathrm{X}-0.030251 \mathrm{X}^{2}+0.00015 \mathrm{X}^{3}\left(\mathrm{R}=.985^{* * *}\right)$

$200 \mathrm{~N}: \mathrm{Y}=4.34552+2.92151 \mathrm{X}-0.092640 \mathrm{X}^{2}+0.00103 \mathrm{X}^{3}\left(\mathrm{R}=.982^{* * *}\right)$

b) Temperature sum $\left(\Sigma^{\circ} \mathrm{C}\right)=\mathrm{X}$

$100 \mathrm{~N}: \mathrm{Y}=5.03977+0.109555 \mathrm{X}-0.000105 \mathrm{X}^{2}+0.000000019 \mathrm{X}^{3}\left(\mathrm{R}=.985^{* * *}\right)$

$200 \mathrm{~N}: \mathrm{Y}=4.41792+0.191482 \mathrm{X}-0.000415 \mathrm{X}^{2}+0.000000327 \mathrm{X}^{3}\left(\mathrm{R}=.978^{* * *}\right)$

From late summer height growth it can be observed that, nitrogen fertilizer begins to have an influence after the $500^{\circ} \mathrm{C}$ temperature sum has been reached. The crop with the lowest nitrogen level (nitrogen fertilization only in the spring) apparently stopped height growth after the depletion of the nitrogen in the soil (Fig. 4). 


\subsubsection{Seeding year yields}

The seeding year yield at the beginning of the growing season is proportional to the seeding density and the maximum yields are achieved by using greater seeding rates (Donald 1951, Baeumer 1964, Baeumer and de Wit 1968). According to Huokuna (1966) the amount of the yield from a forage crop with no companion crop depends on the seeding rate, provided that the field is harvested $70-80$ days after seeding or when it is in the pasture stage. In such a way then, a $10 \mathrm{~kg}$ increase in seed per hectare will provide an increase in dry matter yield of $60-430 \mathrm{~kg} \mathrm{ha}{ }^{-1}$.

With the progression of growth the maximum yield can be achieved from a fluctuating dersity harvested at a later stage of development. Cutting in the middle of the growing phase provides a bigger yield the denser the crop is because the plant competition has not yet noticeably reduced plant growth (Donald 1951).

Competition for light while increasing the growing density also influences the quality of the forage (van BURG 1962). Those plant parts left in shadow begin to form mechanical tissue; in other words, plant tissue with more fibers and less proteins and the result is forage of lower quality.

\section{Results}

The greatest dry matter yield of the seeding year stand at either of the nitrogen levels in the first cutting and in the overall total of the year were achieved with a sowing density of $30 \mathrm{~kg} \mathrm{ha}^{-1}$ (Table 4). In the second cutting the yield differences between seeding densities at both nitrogen levels were not significantly different despite the fact that for all seeding densities up to the greatest the yield mildly rose. The seeding density did not affect the dry matter content of the yield (Table 4). Nitrogen fertilizer had the greatest influence on the dry matter content. In the second cutting, the stand which received an additional $100 \mathrm{~kg} \mathrm{~N} \mathrm{ha}^{-1}$ contained $3.2 \%$ units less dry matter than the stand with $100 \mathrm{~kg} \mathrm{~N} \mathrm{ha}^{-1}$ applied only in the springtime. Also the dry matter content of the total yield fertilized with $200 \mathrm{~kg} \mathrm{~N} \mathrm{ha}^{-1}$ was significantly less than the one with $100 \mathrm{~kg}$ ha. ${ }^{-1}$.

In the first harvest the raw protein content of the dry matter was highest among the two lowest seeding densities. However, the maximum protein yield was achieved with a seeding rate of $60 \mathrm{~kg} \mathrm{ha}^{-1}$ (Table 5). At both levels of nitrogen the highest raw protein content for the second cutting and for the total yield was obtained when the growing density was lowest. Still, the highest protein yield was obtained when the density was highest. 
Table 4. Dry matter yields (DM kg ha-1) and dry matter content (DM \%) of seeding year stand at two levels of nitrogen cut twice in the seeding year.

\begin{tabular}{|c|c|c|c|c|c|c|c|}
\hline \multirow{2}{*}{$\begin{array}{l}\text { Seeding rate } \\
\mathrm{kg} \mathrm{ha-}^{-1}\end{array}$} & \multirow{2}{*}{ Cut 1} & \multicolumn{2}{|c|}{ Cut 2} & \multicolumn{3}{|c|}{ Totals } & \\
\hline & & $100 \mathrm{~N}$ & $200 \mathrm{~N}$ & $100 \mathrm{~N}$ & $200 \mathrm{~N}$ & Avg. & \\
\hline \multicolumn{8}{|c|}{ DM kg ha-1 } \\
\hline 7.5 & $1759 a$ & $1387 \mathrm{a}$ & $2205 a$ & $3054 a$ & $4054 a$ & $3554 a$ & \\
\hline 15 & $2297 b$ & $1567 a$ & $2353 a$ & $3856 \mathrm{ab}$ & $4658 \mathrm{ab}$ & $4257 \mathrm{~b}$ & \\
\hline 30 & $2698 \mathrm{bc}$ & $1571 \mathrm{a}$ & $2580 \mathrm{a}$ & $4188 \mathrm{bc}$ & $5359 \mathrm{bc}$ & $4774 c$ & \\
\hline 60 & $2975 c$ & $1654 a$ & $2639 a$ & $4678 c$ & $5565 c$ & $5123 d$ & \\
\hline \multirow[t]{2}{*}{ Avg. } & 2432 & $1545 \mathrm{~A}$ & $2444 B$ & $3944 \mathrm{~A}$ & $4909 B$ & 4427 & \\
\hline & Cuts & N-Fert. & Density & $\mathrm{CxN}$ & $\mathrm{CxD}$ & $\mathrm{NxD}$ & $\mathrm{CxNxD}$ \\
\hline $\begin{array}{l}\text { F-value } \\
\text { LSD.05 }\end{array}$ & NS & $\begin{array}{c}\mathrm{xx} \\
168 \mathrm{~kg}\end{array}$ & $\begin{array}{c}\mathrm{xxx} \\
233 \mathrm{~kg}\end{array}$ & NS & NS & NS & NS \\
\hline & & DM \% & & & & & \\
\hline 7.5 & 26.1a & $27.3 \mathrm{a}$ & $24.7 \mathrm{a}$ & $26.7 \mathrm{a}$ & $25.2 \mathrm{a}$ & $26.0 \mathrm{a}$ & \\
\hline 15 & 26.1a & 26.1a & $27.8 \mathrm{a}$ & $27.3 \mathrm{a}$ & $24.7 \mathrm{a}$ & $26.0 \mathrm{a}$ & \\
\hline 30 & $25.4 \mathrm{a}$ & $27.7 \mathrm{a}$ & $24.3 \mathrm{a}$ & $26.5 a$ & $24.7 \mathrm{a}$ & $25.6 \mathrm{a}$ & \\
\hline \multirow[t]{3}{*}{60} & $25.6 \mathrm{a}$ & $27.7 \mathrm{a}$ & $24.4 \mathrm{a}$ & $26.5 a$ & $24.8 \mathrm{a}$ & $25.7 \mathrm{a}$ & \\
\hline & 25.8 & $27.2 \mathrm{~B}$ & $25.3 \mathrm{~A}$ & $26.8 B$ & $24.9 \mathrm{~A}$ & 25.9 & \\
\hline & Cuts & N-Fert. & Density & $\mathrm{CxN}$ & $\mathrm{CxD}$ & $\mathrm{NxD}$ & $\mathrm{CxNxD}$ \\
\hline $\begin{array}{l}\text { F-value } \\
\text { LSD. } 05\end{array}$ & NS & $\begin{array}{l}\mathrm{xxx} \\
0.6 \%\end{array}$ & NS & $\begin{array}{l}\mathrm{xx} \\
0.8 \%\end{array}$ & NS & NS & NS \\
\hline
\end{tabular}

Table 5. Protein content $(\%$ in $\mathrm{DM})$ and protein yield $\left(\mathrm{kg} \mathrm{ha}^{-1}\right)$ of seeding year stand at two levels of nitrogen and cut twice in the seeding year.

\begin{tabular}{|c|c|c|c|c|c|c|c|}
\hline \multirow{2}{*}{$\begin{array}{l}\text { Seeding rate } \\
\mathrm{kg} \mathrm{ha}^{-1}\end{array}$} & \multirow{2}{*}{ Cut 1} & \multicolumn{2}{|c|}{ Cut 2} & \multirow[b]{2}{*}{$100 \mathrm{~N}$} & \multirow{2}{*}{$\begin{array}{l}\text { Totals } \\
200 \mathrm{~N}\end{array}$} & \multirow[b]{2}{*}{ Avg. } & \\
\hline & & $100 \mathrm{~N}$ & $200 \mathrm{~N}$ & & & & \\
\hline \multicolumn{8}{|c|}{ Protein \% } \\
\hline 7.5 & $17.6 \mathrm{~b}$ & $15.4 \mathrm{c}$ & $20.8 \mathrm{c}$ & $16.6 \mathrm{c}$ & $19.3 \mathrm{~b}$ & $18.0 \mathrm{c}$ & \\
\hline 15 & $17.4 \mathrm{~b}$ & $13.8 \mathrm{a}$ & $18.6 \mathrm{a}$ & $15.9 \mathrm{~b}$ & $18.0 \mathrm{a}$ & $17.0 \mathrm{~b}$ & \\
\hline 30 & $16.4 \mathrm{a}$ & $13.3 \mathrm{a}$ & $19.8 \mathrm{~b}$ & $15.2 \mathrm{a}$ & $18.0 \mathrm{a}$ & $16.6 \mathrm{a}$ & \\
\hline 60 & $16.1 \mathrm{a}$ & $14.8 \mathrm{~b}$ & $20.1 \mathrm{~b}$ & $15.6 \mathrm{~b}$ & $18.0 \mathrm{a}$ & $16.8 \mathrm{ab}$ & z \\
\hline \multirow[t]{2}{*}{ Avg. } & 16.9 & $14.3 \mathrm{~A}$ & $19.8 \mathrm{~B}$ & $15.8 \mathrm{~A}$ & $18.3 \mathrm{~B}$ & 17.1 & \\
\hline & Cuts & N-Fert. & Density & $\mathrm{CxN}$ & $\mathrm{CxD}$ & $\mathrm{NxD}$ & $\mathrm{CxNxD}$ \\
\hline F-value & NS & $\mathbf{x x}$ & $\mathrm{xxx}$ & $\mathbf{x x x}$ & $\mathbf{x x x}$ & $\mathbf{x x x}$ & $\mathbf{x x x}$ \\
\hline LSD $_{05}$ & & $0.2 \%$ & $0.3 \%$ & $0.2 \%$ & $0.4 \%$ & $0.4 \%$ & $0.6 \%$ \\
\hline \multicolumn{8}{|c|}{ Protein $\mathrm{kg} \mathrm{ha}^{-1}$} \\
\hline 7.5 & $310 \mathrm{a}$ & $214 a$ & $446 a$ & $508 \mathrm{a}$ & $771 a$ & $640 \mathrm{a}$ & \\
\hline 15 & $400 \mathrm{~b}$ & $216 a$ & $453 a$ & $614 b$ & $854 b$ & $734 b$ & \\
\hline 30 & $443 c$ & $219 a$ & $511 b$ & $648 b$ & $967 \mathrm{c}$ & $806 \mathrm{~b}$ & \\
\hline 60 & $479 d$ & $245 a$ & $530 \mathrm{~b}$ & $732 c$ & $1001 \mathrm{c}$ & $867 c$ & \\
\hline \multirow[t]{2}{*}{ Avg. } & 408 & $224 \mathrm{~A}$ & $485 B$ & $626 \mathrm{~A}$ & 899B & 763 & \\
\hline & Cuts & N-Fert. & Density & $\mathrm{CxN}$ & $\mathrm{CxD}$ & $\mathrm{NxD}$ & $\mathrm{CxNxD}$ \\
\hline F-value & NS & $\mathbf{x x x}$ & NS & $\mathbf{x x}$ & NS & NS & NS \\
\hline LSD. $_{05}$ & & $0.6 \%$ & & $0.8 \%$ & & & \\
\hline
\end{tabular}




\section{1.4. Discussion}

Despite good growing conditions the overall average emergence percentage was 33.4. The growth density was directly related to the seeding density. Under dry conditions the competition became so severe, that almost from the beginning of July differences could be distinquished between different seeding densities. In addition, the final percentage of emergence followed, to a great extent, the model of Norrington-Davies and Harries (1977).

Initial growth in a young stand is faster under dense than spaced conditions. At this time LAI is directly proportional to the growing density and a dense stand reaches the optimum LAI sooner (Davidson and Donald 1958, Donald 1963). Also height growth is faster under dense than spaced conditions because competition for light stimulates leaf growth (ALBERDA 1965 a and b). The fact that in this investigation, during the early development stage, the lowest seeding density $\left(7.5 \mathrm{~kg} \mathrm{ha}^{-1} 325\right.$ seeds $\mathrm{m}^{-2}$ ) produced the lowest LAI and height growth lends support to ALBERDA's statement. In contrast to this, at sowing densities of $15 \mathrm{~kg} \mathrm{ha}^{-1}\left(650\right.$ seeds $\left.\mathrm{m}^{-2}\right)$ there were no decisive differences between the different seeding rates LAI's and heights. In addition, the LAI for the lowest seeding density remained less than the others throughout the growing season and continued to grow when the LAI increase for the larger densities had already ceased. Differences in height growth of the seeding densities evened out before the first cutting. In this investigation it was observed, as in many other investigations (DONALD 1951, 1956, BAUMER and de WIT 1968), that during the seeding year it is possible to raise the dry matter yield through increased population density. The growing density influenced the quality of the seeding year yield only in that the raw protein content of DM in the first harvest was reduced. Donald (1951) observed similar results in his investigation. On the basis of the results of this investigation the nitrogen treatment of $200 \mathrm{~kg} \mathrm{~N} \mathrm{ha}^{-1}$ was detrimental during the seeding year and could cause poor wintering.

\section{2. Development and Growth of Stand after Seeding Year}

Developmental rhythm of forage stand

The dry matter yield of a hay crop increases as the stand becomes older (Poijärvi 1931, Agerberg 1943, Huokuna 1960 b, Kivimäe 1965, Hernes 1972, Sau and Virralt 1974, Pestalozzi and Qyen 1977) and its growth follows a sigmoidal curve. In general the spring growth of a hay crop varies from 150 $\mathrm{kg} \mathrm{ha}^{-1}$ to $300 \mathrm{~kg} \mathrm{ha}^{-1}$ of dry matter a day (RInne 1977). According to TeittiNEN (1959) and RAININKo (1968) the greatest possible total dry matter yield can be obtained by harvesting twice during the growing season and, putting off the second cutting for as long as possible because the differences in the regrowth are smaller than in the main yield. Protein production is strongest in the early development stages of the plant. Later the protein content decreases as protein production slackens, irregardless of the fact that the amount of dry matter is still increasing strongly. The fastest production of protein occurs in spring growth when the decrease in protein content is the greatest. 
In later growth phases changes happen more slowly, and during autumn growth the protein yield remains lower than what it was in the early summer (SAU and Virralt 1974).

Changes in quality as the stand ages are associated with the leave/stem relationship and development within the cells (Olofsson 1962). According to Terry and Tilley (1964) and Guequen and Faconneau (1960) the most decisive factor is stem development, because changes in the composition of different plant parts occur in a different way as the stand ages. It is significant that the chemical composition of a plant for a particular development stage is the same during different years under the same growing conditions (PouTIAINEN and RINNE 1971).

The dry matter content is lower in the spring yield than in later yields (Sullivan et al. 1956). Salo et al. (1975) observed a decrease in the dry matter content of timothy and meadow fescue during the spring until the leave/stem ratio fell to $1.0-0.8$. The dry matter content was $15.4-16.8 \%$. After this low point, the dry matter content began to rise.

With favorable weather in the spring the reduction in protein content is rapid. In Finnish investigations the spring decrease in protein content has been 0.4-1.0\% units a day (Huokuna 1971 b, Poutiainen and Rinne 1971, Mela and Poutiainen 1975, Antila 1975, Rinne 1977). In the regrowth the decrease in protein content slows down the closer the end of the growing season approaches (SAU and VirRALT 1974). In the autumn the protein content usually surpasses those of the spring and summer yields (Sullivan et al. 1956, WinkLer et al. 1961, RinNe 1976).

The stems of young forage are more digestible than the leaves up until flowering (Movat et al. 1965). After this point the digestibility reduces faster in the stems than in the leaves. On the whole, the digestibliity of forage drops sharply with the advent of flowering (TERRY and TILLEY 1964). An earlier investigation (PoutiaInen and RINNe 1971) showed that the in vitro digestibility of organic matter of a timothy-fescue mixture at $20 \%$ flowering decreased by $0.47 \%$ units a day. Following this flowering percentage the digestibility dropped by 1.0 unit a day. The lignin content, which increases in the later development stages, reduces forage digestibility relatively linearly even though the fiber content does not increase anymore (AgERBERg 1956, SALo et al. 1975).

Nitrogen and yielding ability of a forage stand

In studies on the affect of nitrogen fertilization on silage stands (LAINE 1966, Giöbel and Steen 1960 and 1965) it has been observed that, the dry matter yield of forage increases linearly up to a fertilization level of $40 \mathrm{~kg} \mathrm{~N}$ $\mathrm{ha}^{-1}$ per cutting. Beyond this level nitrogen provides a still smaller increase in the yield. Beyond a level of $300 \mathrm{~kg} \mathrm{~N}^{-1}$ per season a stand does not produce any further significant increase in the growth of dry matter (LAINE 1954, Jäntti and Köylijärvi 1964, Steen 1968, Rinne 1971, Huokuna 1973, Hunt et al. 1975, Baerung 1977 a). According to Giöbel and Steen (1965) protein production is linear up to a level of $60 \mathrm{~kg} \mathrm{~N} \mathrm{ha}^{-1}$ per cutting. Beyond this level the protein yield increase begins slowly to become smaller. 
Hirvola et al. (1974) suggest that the largest practical amount of nitrogen for protein yield is also $300 \mathrm{~kg} \mathrm{~N} \mathrm{ha-1}$ per season. In late summer and with aging crops the fertilizer optimum becomes less and less. Nitrogen fertilizer reduces the forage's dry matter content in all growth stages (ANTTINEN 1961, Steen 1968, Huokuna 1973, Baerung 1977 b). Steen (1968) found with pasture studies that the dry matter content dropped with nitrogen fertilizer applications of up to $375 \mathrm{~kg} \mathrm{~N} \mathrm{ha}^{-1}$. Applications above this amount encouraged the dry matter content to rise again.

GIÖBEL and STEEN (1965) showed forage protein content to rise almost linearly up to a nitrogen level of $240 \mathrm{~kg} \mathrm{~N} \mathrm{ha}^{-1}$. Hrrvola et al. (1974) and Rinne et al. (1976) found with silage forage cut three times during the summer that in the spring growth the protein content rose linearly at nitrogen levels up to $200 \mathrm{~kg} \mathrm{~N} \mathrm{ha-1}$. For the second and third cuttings the increase in protein content became slower at the highest levels of nitrogen. The greatest rise in protein content, $4.2 \%$ units, was obtained by applying from 50 to $100 \mathrm{~kg} \mathrm{~N} \mathrm{ha}^{-1}$ per cut (RINNE et al. 1976).

The minimum allowable protein content for cattle feed, $16-18 \%$ of the dry matter, can be achieved by cutting the crop three times and applying nitrogen 250-300 kg N ha-1 (Нuokuna 1970, $1971 \mathrm{~b}, 1973,1976$ ).

The decrease in hay digestibility because of stand ageing cannot be compensated for by applying more nitrogen fertilizer (STEEN 1968, Willman 1975). Poutiainen and Rinne (1976) showed that of silage forage components, only protein digestibility improved from nitrogen application. The effect of nitrogen on the digestibility of the other components was not statistically significant.

Population density in relation to the growth and development of the stand

WiLson (1960) stressed that stand height depends on the competition within the stand for light. Regarding the utilization of light, it is important that the crop's assimilated surface be evenly distributed along the vertical axis. In this manner each part of the stand receives a balanced amount of light and even with a small LAI a great amount of growth can be obtained. According to KELLY (1958) the stand's height and stem formation greatly affect the spring growth because the greatest amount of the shoots are generative. In midsummer a plant usually forms new shoots, which means that the stand height alone does not determine the yield. In the autumn neither of the aforementioned factors prevail, they both influnce the yield. The use of light related to the effective height growth in late stages of development is rather limited because of the decrease in the assimilation rate. Such factors related to the decrease are canopy formation, cessation of shooting and the influence of increasing shadow on the acceleration of old leaf withering (MICHELL and CALDER 1958).

According to Brown and BLAzER (1968) the maximum crop yield can be achieved by maintaining the optimal LAI which is related to the desired growth rate as compared to a momentarily high one. However, during the growing season there may be various optimum LAI's. The lowest LAI's 
promote shooting. On the other hand, the biggest LAI values may be needed for production of dry hay or pasturing frequently. The maximum seeding year yields are obtained by making good use of LAI in connection with a large population density. Over successive growing seasons, however, the stand conforms to its environment. In regard to competition, the crop becomes dense or thins to achieve a balanced state (Donald 1956). As the stand ages there are accompanying changes in the population density such that the less dense stands produce greater yields (LAine 1958, Nishimura and Nitta 1974). The effect of applying fertilizer is that for each level of nitrogen a characteristic maximum yield is obtained with increasing population densities (DONALD 1951, Norrington-Davies and Growley 1969).

Population density increases competition for light which in turn encourages lengthwise growth in the leaves. This has the effect of influencing a color change in the leaves to light green and etiolating the internodes (AlBERDA 1965 b). An increase in population density lowers the plant's nitrogen content (Donald 1951) and the plant parts left in the shade begin to produce mechanical tissue which reduces the quality of the forage.

\section{2.1. Spring growth and development}

In the actual production years 1976-77, the spring growth comprised the first cut of the 2-, 3 and 4-cut systems. The spring growth had the characteristic that each of the influencing growth and development factors individually increased LAI, dry matter content and yield while at the same time reduced

Table 6. The correlation coefficients between growth factors and some parameters describing the development of spring growth of the stand.

\begin{tabular}{|c|c|c|c|c|c|}
\hline & LAI & DM \% & DM yield & Prot. \% & Cell. dig. $\%$ \\
\hline Crowing days $\ldots \ldots \ldots \ldots . . . .$. & $.625^{*}$ & $.730^{* *}$ & $.994 * * *$ & $-.740 * *$ & $-.967 * * *$ \\
\hline$\Sigma>0^{\circ} \mathrm{C}$ (temp.) .......... & .354 & $.893 * * *$ & $.945^{* * *}$ & $-.841 * * *$ & $-.953 * * *$ \\
\hline$\Sigma$ Whem- ${ }^{2}$ (rad.) .......... & .247 & $.909 * * *$ & $.895 * * *$ & $-.869 * * *$ & $-.930 * * *$ \\
\hline$\Sigma \mathrm{mm}$ (prec.) $\ldots . \ldots \ldots \ldots . . .$. & $.651^{*}$ & $.725^{* *}$ & $.977 * * *$ & $-.658^{*}$ & $-.909 * * *$ \\
\hline kg N ha-1 ................. & .300 & $.602^{*}$ & .552 & -.187 & $-.379^{*}$ \\
\hline
\end{tabular}

the protein content and cellulase digestibility of dry matter. Of the influencing factors on spring growth, the one with the smallest correlation to the yield was nitrogen fertilization (Table 6). The LAI for spring growth had the highest correlation with the precipitation of the growing period. Nevertheless, the highest determination coefficient for spring growth LAI, 81,6\% (F-value = $\left.19.945^{* * *}\right)$, was given by the regression model : $\mathrm{Y}=-3.1572+0.3971 \mathrm{X}_{1}-$ $0.0218 \mathrm{X}_{2}$

where $\mathrm{X}_{1}=$ growing days

$\mathrm{X}_{2}=$ temperature sum in degree days $\left(\Sigma>0^{\circ} \mathrm{C}\right)$

Spring growth's dry matter content correlated best with the spring radiation energy sum. In the selective regression analysis the dry matter content 
depended so heavily on the radiation energy sum that no other factors within the given limits $(\mathrm{P}=.90)$ fit into the model

$\mathrm{Y}=13.248+0.457 \mathrm{X}\left(\mathrm{R}^{2}=82.6 \%, \quad \mathrm{~F}\right.$-value $\left.=47.4 * * *\right)$

The spring growth dry matter yield had the best correlation with growing days $\left(\mathrm{R}=.994^{* * *}\right)$. The regression model for dry matter yield was $\mathrm{Y}=3198.031+115.3085 \mathrm{X}_{1}-6.1056 \mathrm{X}_{2}+1.8524 \mathrm{X}_{3}+16.0215 \mathrm{X}_{4}$ $\left(\mathrm{R}^{2}=99.9 \%\right.$, F-value $\left.=1245.13^{* * *}\right)$

where $\mathrm{X}_{1}=$ growing days

$\mathrm{X}_{2}=$ nitrogen fertilization for the cut $\left(\mathrm{kg} \mathrm{N} \mathrm{ha}^{-1}\right)$

$\mathrm{X}_{3}=$ temperature sum in degree days $\left(\Sigma>0{ }^{\circ} \mathrm{C}\right)$

$\mathrm{X}_{\mathbf{4}}=$ precipitation $(\Sigma \mathrm{mm})$

The spring growth's protein content correlated strongest with the growing period's radiation energy sum $(\mathrm{R}=-.869 * * *)$. The highest determination coefficient $93.0 \%\left(\mathrm{~F}\right.$-value $\left.=59.757^{* * *}\right)$, for protein content was provided by the regression model $\mathrm{Y}=26.2261-0.6595 \mathrm{X},+0.061 \mathrm{X}_{2}$

where $\mathrm{X}_{1}=$ total radiation $\left(\Sigma \mathrm{Wh} \mathrm{cm}^{-2}\right)$

$\mathrm{X}_{2}=$ nitrogen fertilization for the cut $\left(\mathrm{kg} \mathrm{N} \mathrm{ha}^{-1}\right)$

The DM cellulase digestibility of the spring growth correlated best with the growing days $\left(\mathrm{R}=-.967^{* * *}\right)$. The regression model was $\mathrm{Y}=136.9089-1.3114 \mathrm{X}_{1}-0.6540 \mathrm{X}_{2}-8.7564 \mathrm{X}_{3}+0.456 \mathrm{X}_{4}$ $\left(\mathrm{R}^{2}=99.1 \%, \mathrm{~F}\right.$-value $\left.=188.703^{* * *}\right)$

where $\mathrm{X}_{1}=$ growing days

$\mathrm{X}_{2}=$ precipitation $(\Sigma \mathrm{mm})$

$\mathrm{X}_{\mathbf{3}}=$ total radiation $\left(\Sigma \mathrm{Wh} \mathrm{cm}^{-2}\right)$

$\mathrm{X}_{4}=$ temperature sum in degree days $\left(\Sigma>0^{\circ} \mathrm{C}\right)$

\subsubsection{Summer growth and development}

Midsummer temperature and radiation intensities are high and most often there is a prevailing scarcity of water. Summer growth comprised the second cut in the 3- and 4-cut systems as well as the third cut in the 4-cut system.

The midsummer changes in crop growth were noticeably more irregular than during the spring. Only five statistically significant correlations were observed between the factors describing the yield and the growth factors (Table 7).

Table 7. The correlation coefficients between growth factors and some parameters describing the development of the summer growth of the stand.

\begin{tabular}{|c|c|c|c|c|c|}
\hline & LAI & DM \% & DM yield & Prot. $\%$ & Cell. dig \% \\
\hline Growing days .................. & .220 & $-.670^{*}$ & .345 & -.160 & -.397 \\
\hline$\Sigma>0{ }^{\circ} \mathrm{C}$ (temp.) .............. & .186 & -.559 & .120 & 0 & -.104 \\
\hline$\Sigma \mathrm{Whcm}^{-2}$ (rad.) ............. & -.081 & -.156 & .055 & .048 & $-.775 * *$ \\
\hline 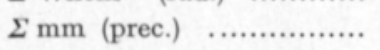 & .340 & $-.589^{*}$ & .341 & .120 & -.297 \\
\hline$\Sigma \mathrm{mm}^{1}{ }^{1}$ (prec.) & .198 & -.448 & .360 & -.331 & .324 \\
\hline $\left.\mathrm{kg} \mathrm{ha}^{-1}{ }^{2}\right) \ldots \ldots \ldots \ldots \ldots \ldots \ldots$ & -.011 & -.199 & -.021 & .045 & -.530 \\
\hline 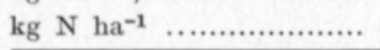 & $.635^{*}$ & -.380 & .199 & $.716^{* *}$ & -.120 \\
\hline
\end{tabular}

1) Precipitation $\mathrm{mm}$ during one week before previous cut

2) yield $\mathrm{kg} \mathrm{ha}^{-1}$ in the earlier cut. 
In the selective regression model only nitrogen fertilization had statistically significant influence on LAI development. The model was $\mathrm{Y}=1.5133+0.0364 \mathrm{X}\left(\mathrm{R}^{2}=40.4 \%\right.$, F-value $\left.6.773^{*}\right)$

The dry matter content had a strong correlation $\left(\mathrm{R}=-.670^{*}\right)$ to the midsummer growing days. The regression model which gave the best determination coefficient $\left(80.8 \%, \quad\right.$ F-value $\left.=7.358^{*}\right)$ was $\mathrm{Y}=44.0798-0.5364 \mathrm{X}_{1}+0.0024 \mathrm{X}_{2}-0.0497 \mathrm{X}_{3}-0.0405 \mathrm{X}_{4}$

where $\mathrm{X}_{1}=$ growing days

$\mathrm{X}_{2}=$ previous cut's yield $\left(\mathrm{kg} \mathrm{ha}^{-1}\right)$

$\mathrm{X}_{3}=$ nitrogen fertilization for the cut $\left(\mathrm{kg} \mathrm{N} \mathrm{ha}^{-1}\right)$

$\mathrm{X}_{4}=$ precipitation $(\Sigma \mathrm{mm})$

All of the growth influencing factors investigated poorly described the development of the dry matter yield. In the selective regression analysis all variables remained below the given limits $(\mathrm{P}=.90)$.

Nitrogen fertilizer was the factor affecting the protein content development the most $\left(\mathrm{R}=.716^{* *}\right)$. The following regression model gave the highest coefficient of determination $(85.6 \%, \quad \mathrm{~F}$-value $=10.389 * *)$ $\mathrm{Y}=22.39065+0.1416 \mathrm{X}_{1}-1.1480 \mathrm{X}_{2}+0.0448 \mathrm{X}_{3}+0.0392 \mathrm{X}_{4}$

where $\mathrm{X}_{1}=$ nitrogen fertilization for the cut $\left(\mathrm{kg} \mathrm{N} \mathrm{ha}^{-1}\right)$

$\mathrm{Z}_{2}=$ growing days

$\mathrm{X}_{3}=$ temperature sum in degree days $\left(\Sigma>0{ }^{\circ} \mathrm{C}\right)$

$\mathrm{X}_{4}=$ precipitation $(\mathrm{\Sigma mm})$

Concerning the DM cellulase digestibility of the summer growth, the following regression model gave the highest coefficient of determination $(97.8 \%$, F-value $=79.308 * * *)$ $\mathrm{Y}=83.0525+0.2060 \mathrm{X}_{1}+0.1308 \mathrm{X}_{2}-2.7610 \mathrm{X}_{3}+0.0262 \mathrm{X}_{4}$

where $\mathrm{X}_{1}=$ precipitation during the week before the previous cut $(\Sigma \mathrm{mm})$

$\mathrm{X}_{2}=$ temperature sum in degree days $\left(\Sigma>0^{\circ} \mathrm{C}\right)$

$\mathrm{X}_{3}=$ growing days

$\mathrm{X}_{4}=$ nitrogen fertilization for the cut $\left(\mathrm{kg} \mathrm{N} \mathrm{ha}^{-1}\right)$

\subsubsection{Fall growth and development}

In late summer the day length shortens, daytime and especially nighttime temperatures drop and the radiation intensity in particular decreases. On the other hand, rainfall is abundant and this abundance is not a limiting growth factor at this time as it was in midsummer. Also the autumn growth changes are more irregular than those of the spring but are not as irregular as the summer ones. All of the final cuts of the various cutting systems are categorized under fall cuttings.

Growth factor influence on fall growth LAI was not determined because the autumn LAI was recoredd only for 1976.

The highest coefficient of determination for fall growth's dry matter content $\left(95.1 \%, \quad \mathrm{~F}\right.$-value $\left.=33.837^{* * *}\right) \quad$ was obtained with the following regression model $\mathrm{Y}=22.531+0.50428 \mathrm{X}_{1}-0.05237 \mathrm{X}_{2}-0.00101 \mathrm{X}_{3}-0.11299 \mathrm{X}_{4}$ where $\mathrm{X}_{1}=$ total radiation $\left(\Sigma \mathrm{Wh} \mathrm{cm}^{-2}\right)$

$\mathrm{X}_{2}=$ nitrogen fertilization for the cut $\left(\mathrm{kg} \mathrm{N} \mathrm{ha}^{-1}\right)$

$\mathrm{X}_{3}=$ previous cut's yield (DM $\mathrm{kg} \mathrm{ha}^{-1}$ )

$\mathrm{X}_{4}=$ precipitation during the week before the previous cut $(\Sigma \mathrm{mm})$ 
Table 8. The correlation coefficients between growth factors and some parameters describing the development of the fall growth of the stand.

\begin{tabular}{|c|c|c|c|c|}
\hline & DM $\%$ & DM yield & Prot. \% & Cell. dig. $\%$ \\
\hline Growing days .................. & .550 & $.760 * *$ & -.504 & $-.788 * *$ \\
\hline$\Sigma>0^{\circ} \mathrm{C}$ (temp.) .................. & $.605^{*}$ & $.716^{* *}$ & -.487 & $-.737 * *$ \\
\hline$\Sigma \mathrm{Whcm}^{-2}$ (rad.) ................ & $.663^{*}$ & $.631^{*}$ & -.443 & $-.637^{*}$ \\
\hline$\Sigma \mathrm{mm}$ (prec.) & .277 & $.828 * * *$ & -.508 & $-.862 * * *$ \\
\hline $\mathrm{mm}^{1}$ ) (prec.) & -.331 & .215 & -.205 & -.285 \\
\hline $\left.\mathrm{kg} \mathrm{ha}^{-1}{ }^{2}\right)$ & .248 & $.638^{*}$ & -.321 & $-.670^{*}$ \\
\hline kg N $\mathrm{ma}^{-1} \ldots \ldots \ldots \ldots \ldots \ldots$ & -.037 & $.782^{* *}$ & .294 & -.319 \\
\hline
\end{tabular}

1) Precipitation $\mathrm{mm}$ during one week before previous cut.

$\left.{ }^{2}\right)$ yield $\mathrm{kg} \mathrm{ha}^{-1}$ in the earlier cut.

Whereas the dry matter yield of the summer growth did not correlate with any of the growth factors, the yield from the fall growth was found to correlate with the precipitation measured during the week before the previous cut (Table 8$)$. The best regression model for the dry matter yield was $\left(\mathrm{R}^{2}=93.9 \%\right.$, $\mathrm{F}$-value $\left.=40.720^{* * *}\right)$

$\mathrm{Y}=-1249.79+13.7815 \mathrm{X}_{1}+19.6328 \mathrm{X}_{2}+53.190 \mathrm{X}_{3}$

where $\mathrm{X}_{1}=$ precipitation $(\Sigma \mathrm{mm})$

$\mathrm{X}_{2}=$ nitrogen fertilization for the cut $\left(\mathrm{kg} \mathrm{N} \mathrm{ha}^{-1}\right)$

$\mathrm{X}_{3}=$ precipitation during the week before the previous cut $(\Sigma \mathrm{mm})$

The dependence of the fall growth's protein content on one separate growth factor turned out to be low. The protein content development was best described by the following regression model $\left(\mathrm{R}^{2}=93.1 \%, \mathrm{~F}\right.$-value $\left.=36.253^{* * *}\right)$ $\mathrm{Y}=18.4625-0.0195 \mathrm{X}_{1}+0.1029 \mathrm{X}_{2}-0.1470 \mathrm{X}_{3}$

where $\mathrm{X}_{1}=$ precipitation $(\Sigma \mathrm{mm})$

$\mathrm{X}_{2}=$ nitrogen fertilization for the cut $\left(\mathrm{kg} \mathrm{N} \mathrm{ha}^{-1}\right)$

$\mathrm{X}_{3}=$ growing days

For depicting the cellulase digestibility of the fall growth the following regression model was used $\mathrm{Y}=70.4166-0.1010 \mathrm{X}_{1}-0.2720 \mathrm{X}_{2}$

where $\mathrm{X}_{1}=$ precipitation $(\Sigma \mathrm{mm})$

$\mathrm{X}_{2}=$ precipitation during the week before the previous cut $(\Sigma \mathrm{mm})$

The coefficient of determination for changes in the DM cellulase digestibility was $86.8 \%$ (F-value $\left.=29.496^{* * *}\right)$.

4.2.4. Growing time and temperature relations to growth and development characters of a forage stand

The growing days and the temperature sum in degree days are the most important factors upon which the descriptive factors of spring, summer and fall growth depend. These two factors are basic growing conditions for forage crops in Finland. 


\section{Spring growth}

In general, all of the investigated characters related to the yield of spring growth showed relatively strong changes. All regression equations were of the third degree which had very high statistical significance. The independent variables in the regression equations were either growing time (a) or temperature sum in degree days (b). The regression equations were as follows (Fig. 5).

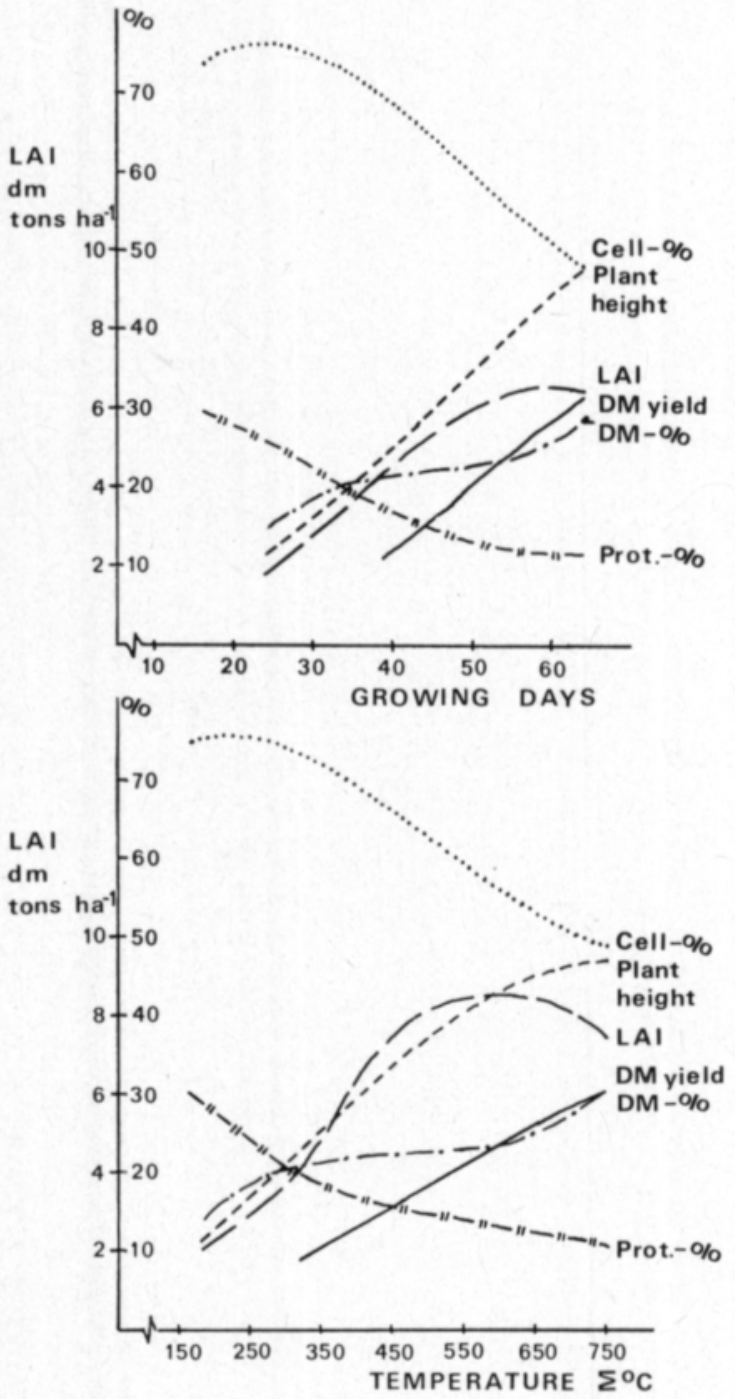

Fig. 5. Spring development and growth of the fesque stand after seeding year in relation to the growing days and to the temperature conditions in degree days.

1. LAI

a) $\mathrm{Y}=0.009661-0.054069 \mathrm{X}+0.007144 \mathrm{X}^{2}-0.000074 \mathrm{X}^{3}$

$(\mathrm{R}=.876 * * *)$

b) $\mathrm{Y}=0.043788+0.006107 \mathrm{X}+0.000033 \mathrm{X}^{2}-0.00000004 \mathrm{X}^{3}$

$\left(\mathrm{R}=.836^{* * *}\right)$

2. Stand height

a) $\mathrm{Y}=0.532344+0.255315 \mathrm{X}+0.033959 \mathrm{X}^{2}-0.000230 \mathrm{X}^{3}$

$\left(\mathrm{R}=.988^{* * *}\right)$

b) $\mathrm{Y}=0.759275+0.077105 \mathrm{X}+0.000295 \mathrm{X}^{2}-0.00000031 \mathrm{X}^{3}$

$(\mathrm{R}=.995 * * *)$ 
3. Dry matter content

a) $\mathrm{Y}=-36.474+3.74591 \mathrm{X}-0.08198 \mathrm{X}^{2}+0.000615 \mathrm{X}^{3}$

$(\mathrm{R}=.868 * * *)$

b) $\mathrm{Y}=-12.4056+0.21366 \mathrm{X}-0.044399 \mathrm{X}^{2}+0.000031 \mathrm{X}^{3}$

$\left(\mathrm{R}=.973^{* * *}\right)$

4. Dry matter yield

a) $\mathrm{Y}=0.792528-65.7417 \mathrm{X}+4.21189 \mathrm{X}^{2}-0.026107 \mathrm{X}^{3}$

$(\mathrm{R}=.998 * * *)$

b) $\mathrm{Y}=5.75349-1.65495 \mathrm{X}+0.027957 \mathrm{X}^{2}-0.00007 \mathrm{X}^{3}$

$\left(\mathrm{R}=.977^{* * *}\right)$

5. Protein content

a) $\mathrm{Y}=33.6065-0.013368 \mathrm{X}-0.018151 \mathrm{X}^{2}+0.000204 \mathrm{X}^{3}$

$\left(\mathrm{R}=.917^{* * *}\right)$

b) $\mathrm{Y}=52.1947-0.167158 \mathrm{X}+0.000254 \mathrm{X}^{2}-0.00000014 \mathrm{X}^{3}$

$(\mathrm{R}=.952 * * *)$

6. Cellulase content

a) $\mathrm{Y}=51.0319+2.36978 \mathrm{X}-0.06537 \mathrm{X}^{2}+0.000431 \mathrm{X}^{3}$

$\left(\mathrm{R}=.955^{* * *}\right)$

b) $\mathrm{Y}=60.1753+0.150145 \mathrm{X}-0.000428 \mathrm{X}^{2}+0.00000028 \mathrm{X}^{3}$

$\left(\mathrm{R}=.966^{* * *}\right)$

Summer growth

The correlation of midsummer growth to growing days and temperature sum in degree days was less and noticeably less, respectively, than for spring

Fig. 6. Summer development and growth of the fesque stand after seeding year in relation to the growing days and to the temperature conditions in degree days.
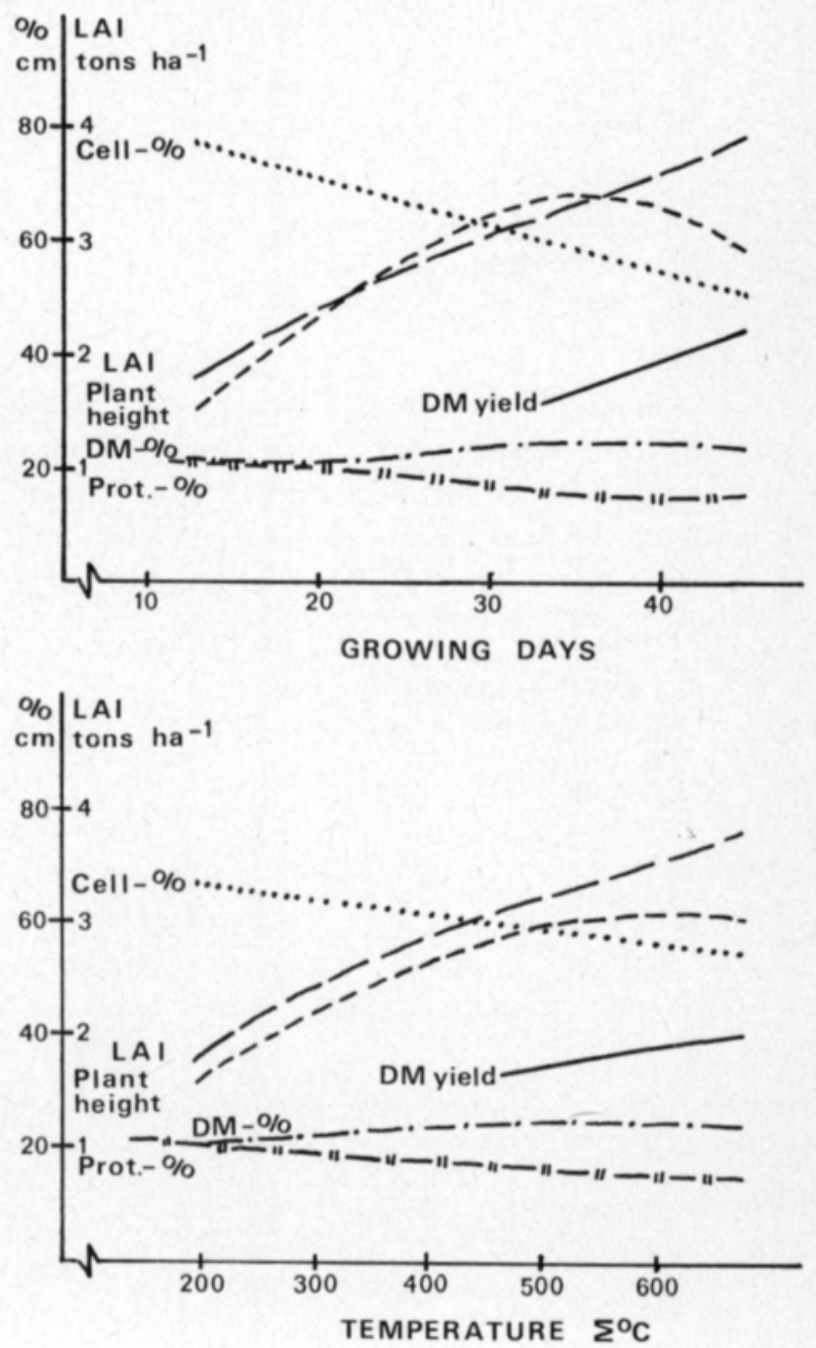
growth. In particular, midsummer growth had especially slow changes in the dry matter and protein contents. Also, the cellulase digestibility of dry matter dropped relatively slowly and linearly. The independent variables for midsummer growth were either growing time (a) or temperature sum in degree days (b). The regression equations were as follows (Fig. 6):

1. LAI

a) $\mathrm{Y}=-0.025061+0183391 \mathrm{X}+0.00389 \mathrm{X}^{2}-0.000039 \mathrm{X}^{3}$

$\left(\mathrm{R}=.853^{* * *}\right)$

b) $\mathrm{Y}=-0.029375+0.012003 \mathrm{X}-0.0000155 \mathrm{X}^{2}+0.000000009 \mathrm{X}^{3}$

$\left(\mathrm{R}=.850^{* * *}\right)$

2. Stand height

a) $\mathrm{Y}=5.14303+1.28261 \mathrm{X}+0.073425 \mathrm{X}^{2}-0.0016839 \mathrm{X}^{3}$

b) $\mathrm{Y}=4.98153+0.146748 \mathrm{X}-0.0000223 \mathrm{X}^{2}-0.00000011 \mathrm{X}^{3}$

$(\mathrm{R}=.992 * * *)$

3. Dry matter content

a) $\mathrm{Y}=24.5757-0.624244 \mathrm{X}+0.03392 \mathrm{X}^{2}-0.0004598 \mathrm{X}^{3}$

$\left(\mathrm{R}=.988^{* * *}\right)$

b) $\mathrm{Y}=18.1263+0.009892 \mathrm{X}+0.000026 \mathrm{X}^{2}-0.00000004 \mathrm{X}^{3}$

$\left(\mathrm{R}=.486^{* *}\right)$

$\left(\mathrm{R}=.505^{* *}\right)$

4. Dry matter yield

a) $\mathrm{Y}=4.591+42.442 \mathrm{X}+0.15536 \mathrm{X}^{2}$

b) $\mathrm{Y}=20.4374+4.79395 \mathrm{X}-0.27944 \mathrm{X}^{2}$

$(\mathrm{R}=.822 * * *)$

$\left(\mathrm{R}=.791^{* * *}\right)$

5. Protein content

a) $\mathrm{Y}=16.3465+0.89533 \mathrm{X}-0.04697 \mathrm{X}^{2}+0.00059 \mathrm{X}^{3}$

$\left(\mathrm{R}=.626^{* * *}\right)$

b) $\mathrm{Y}=23.6649-0.018688 \mathrm{X}+0.0000091 \mathrm{X}^{2}-0.000000001 \mathrm{X}^{3}$

$\left(\mathrm{R}=.598^{* * *}\right)$

6. Cellulase digestibility $-\%$

a) $\mathrm{Y}=89.0095-0.945977 \mathrm{X}+0.002175 \mathrm{X}^{2} \quad\left(\mathrm{R}=.702^{* *}\right)$

b) $\mathrm{Y}=70.6825-0.02441 \mathrm{X}$

$(\mathrm{r}=.381 \mathrm{NS})$

\section{Fall growth}

The changes in dry matter and protein contents occurred relatively slowly also during late summer, LAI did not reach its maximum in the autumn despite a growing period of 90 days in the 2 -cut system. The regression equations for late summer growth with the independent variables of either growing period (a) or temperature sum in degree days (b) were as follows (Fig. 7):

1. LAI

a) $\mathrm{Y}=-0.104588+0.109084 \mathrm{X}-0.000270 \mathrm{X}^{2}$

$\left(\mathrm{R}=.853^{* *}\right)$

b) $\mathrm{Y}=-0.129214+0.908704 \mathrm{X}-0.0247926 \mathrm{X}^{2}$

$\left(\mathrm{R}=.853^{* *}\right)$

2. Dry matter content

a) $\mathrm{Y}=22.1133-0.251295 \mathrm{X}+0.005943 \mathrm{X}^{2}-0.0000258 \mathrm{X}^{3}$

$\left(\mathrm{R}=.638^{* * *}\right)$

b) $\mathrm{Y}=16.2234+0.020281 \mathrm{X}-0.000035 \mathrm{X}^{2}+0.00000002 \mathrm{X}^{3}$

$\left(\mathrm{R}=.566^{* * *}\right)$

3. Dry matter yield

a) $\mathrm{Y}=-8.71256-10.0924 \mathrm{X}+1.15345 \mathrm{X}^{2}-0.006842 \mathrm{X}^{3}$

$\left(\mathrm{R}=.877^{* * *}\right)$

b) $\mathrm{Y}=13.8027-0.988314 \mathrm{X}+0.0083108 \mathrm{X}^{2}-0.0000044 \mathrm{X}^{3}$

$\left(\mathrm{R}=.863^{* * *}\right)$

4. Protein content

a) $\mathrm{Y}=23.0423+0.06078 \mathrm{X}-0.006185 \mathrm{X}^{2}+0.000046 \mathrm{X}^{3}$

$\left(\mathrm{R}=.808^{* * *}\right)$

b) $\mathrm{Y}=24.6414-0.006555 \mathrm{X}-0.000012 \mathrm{X}^{2}+0.000000008 \mathrm{X}^{3}$

$\left(\mathrm{R}=.746^{* * *}\right)$

5. Cellulase digestibility $-\%$

a) $\mathrm{Y}=75.4445-0.36397 \mathrm{X}+0.000866 \mathrm{X}^{2}$

b) $\mathrm{Y}=73.084-0.027699 \mathrm{X}+0.0000077 \mathrm{X}^{2}$

$$
\begin{aligned}
& (\mathrm{R}=.806 * *) \\
& \left(\mathrm{R}=.743^{* *}\right)
\end{aligned}
$$




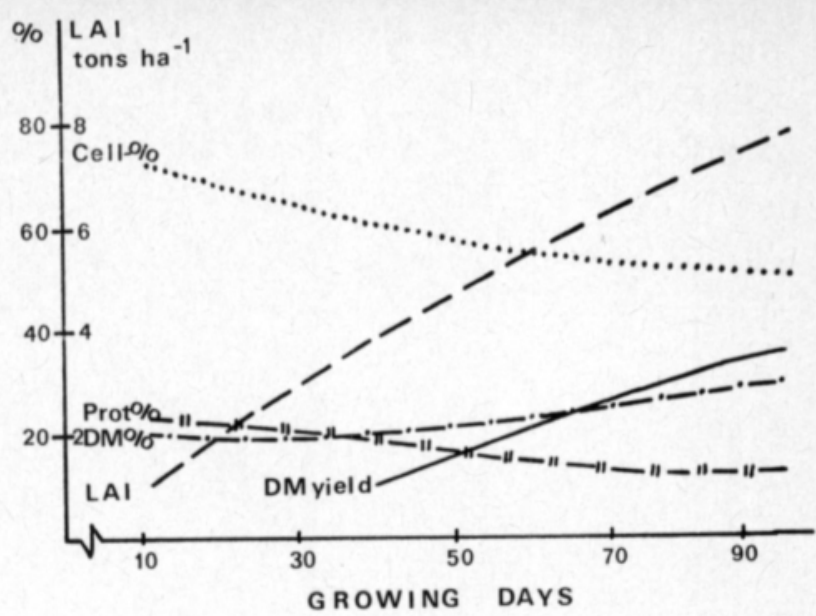

Fig. 7. Autumn development and growth of the fesque stand after seeding year in relation to the growing days and to the temperature conditions in degree days.

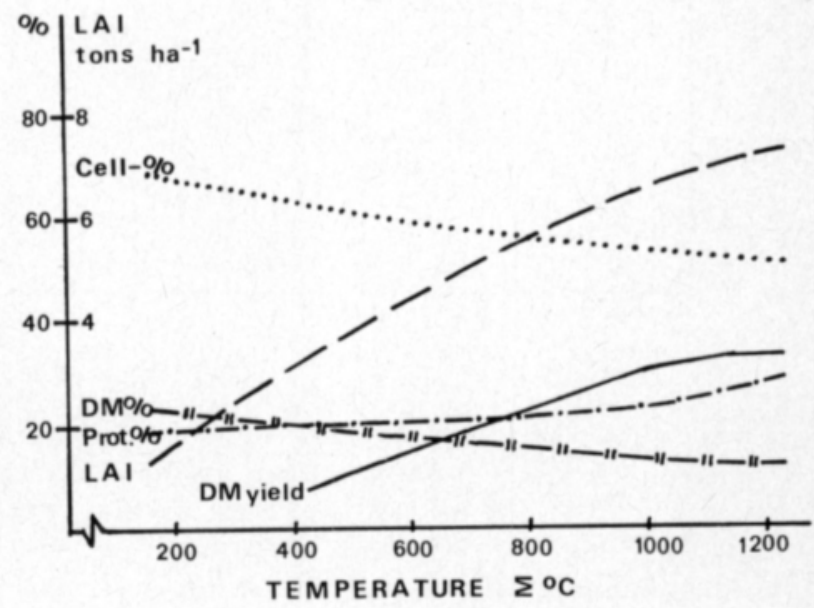

For the 1976-77 cuttings also the relationships between LAI and dry matter yield were determined (Fig. 8). During spring growth the dry matter yield increased rather sharply as LAI increased. However, as LAI increased over the growing period the resulting increase in yield slowly decreased, but at the same time significance of the liner regression line improved.

\section{2.5. Discussion}

The growing conditions under which forage yield development is the most effective in Finland, occur in early summer. Because of long days there is abundant light, the radiant intensity is high, temperatures are relatively high and the amount of water for plant utilization in the soil is sufficient. However, a scarcity of water can limit the benefits of the other aforementioned conditions. In the autumn there is abundant water for plants, but light and temperature become the limiting factors. In addition, growth slows down anyway in the autumn because the plant gradually starts to prepare for wintering (RAPPE 1948).

The regression models describing the yield show that the yield forming characteristics of spring growth experienced faster changes than the yield 


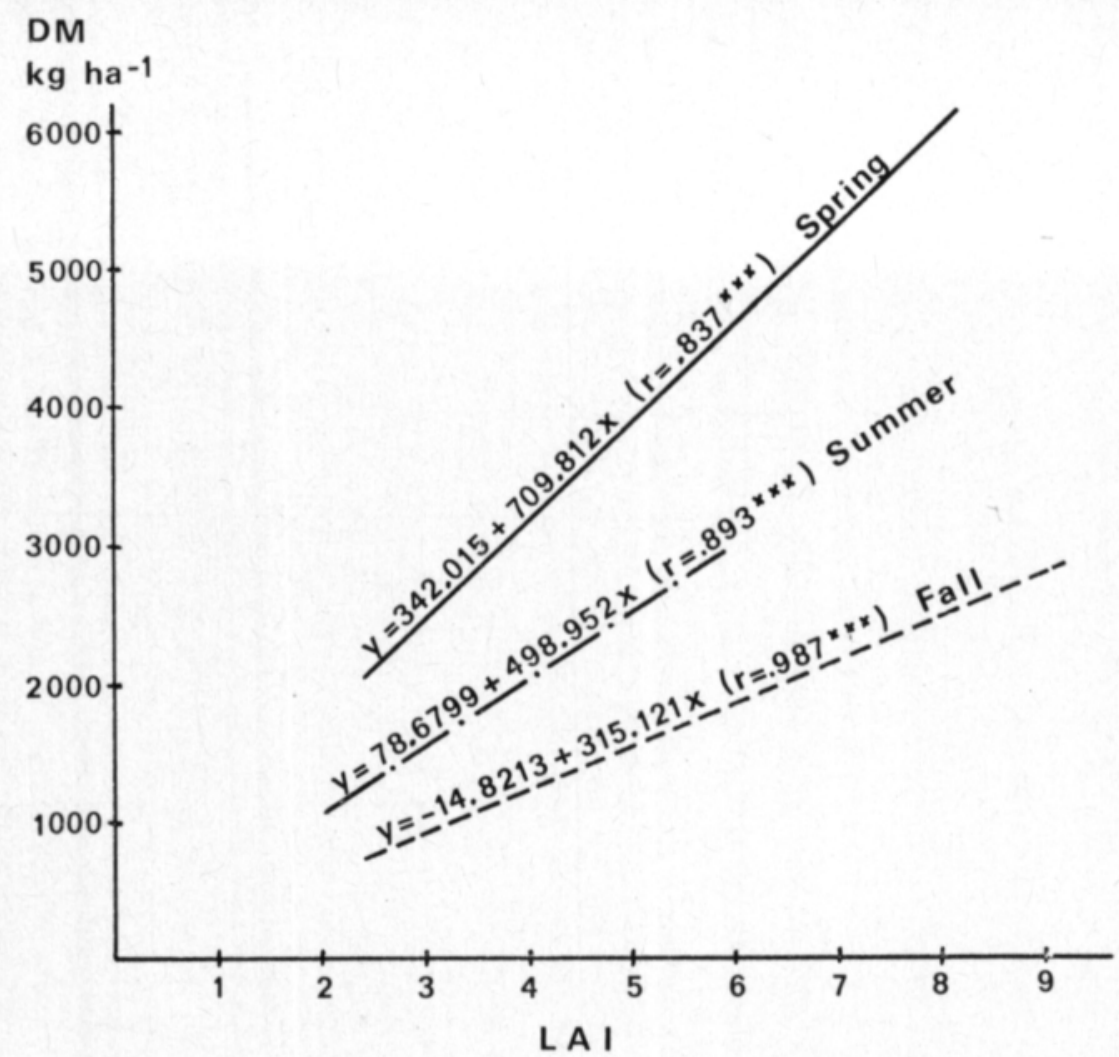

Fig. 8. The relationship between the dry matter yield (DM kg ha-1) and leaf area index (LAI) in spring, summer and autumn growth.

quality characters of mid and late summer growth. These results agreed with those of many previous investigations (HUOKUnA 1964 and 1973, PoutiaineN and Rinne 1971, SyrJälä 1973 and 1974, Hirvola et al. 1974, Salo et al. 1975, Rinne 1977). The growth factors which best described the spring growth DM yield were growing days, temperature sum in degree days and total radiation.

Midsummer growth is most often limited by a shortage of water. By applying nitrogen fertilizer it is possible, in part, to overcome the effect of drought (MELA 1974), and therefore the fertilizer displays a more noticeable influence on midsummer growth than spring growth. An important factor to ensure establishment of a sufficient assimilative surface is enough water immediatly after cutting. In the midsummer regression model the most important variables affecting the yield were the amount of nitrogen applied precipitation, and the precipitation during the week before the prior cutting. What is particularly worth considering is the low coefficient of determination in the selective regression model, while in the descriptive parabola for the dry matter yield both the growing time and the temperature sum in degree days were statistically highly significant.

Not including the dry matter content, in the regression model for fall growth the factor which best described crop growth was the late summer precipitation. The regression model for the fall DM yield surprisingly set the precipitation, the 
amount of nitrogen applied and the precipitation during the week before the prior cutting as the most determining factors; presumably due to the dominant weather conditions. During the investigation years, August remained noticeably below the long-term average and, the abundant September rains could not counteract the stop in growth which occurred in August because the other growth factors decreased at the same time. According to the regression model, precipitation reduces the protein content and cellulase digestibility of the DM yield. Olofsson (1962) and SALo et al. (1975) suggest that in grasses ample moisture easily increases the amount of mechanical tissue at the expense of digestible material.

LAI and dry matter yield had extremely statistically significant correlations with spring, summer and fall growth. The significance was lowest in the spring when stem formation was strongest and the highest for the leafy autumn yield.

During spring growth an increase in LAI of one LAI-unit increased the yield by $710 \mathrm{~kg} \mathrm{ha}^{-1}$. The maximum LAI of 8.5 was reached $50-60$ days after the initiation of growth in the spring, at which time it began to decrease but the stand's height still increased. The maximum LAI for spring growth was achieved with a temperature sum of $550^{\circ} \mathrm{C}\left(\Sigma>0^{\circ} \mathrm{C}\right)$.

The reduction in LAI at the end of the spring growth shows that a crop left growing longer would have gone beyond the optimum cutting time as determined with the aid of LAI (BROwN and BLASER 1968) even though the height was still increasing. The LAI's determined in this investigation corresponded with those of previous studies (BRougham 1958, Evans 1964, RAININKO 1968).

The protein content dropped sharply in the temperature range of $150-$ $350^{\circ} \mathrm{C}$, where a rise in cumulative temperature sum of $10^{\circ} \mathrm{C}$ induced a $0.17 \%$ units decrease in protein content. At the same time, every $10^{\circ} \mathrm{C}$ increase caused a $0.4 \%$ units increase in dry matter content. The second intensive increase in dry matter content begins during the growth stage where LAI reaches its maximum. The digestibility of dry matter improves in the spring and then begins to decrease a little bit later than the protein content does. Cellulase digestibility of dry matter declines in the temperature range of $250-650^{\circ} \mathrm{C}$, where a $10^{\circ} \mathrm{C}$ rise reduces digestibility by abount $0.6 \%$ units.

In 45 growing days the midsumer LAI reached a value of 4 , and an one LAI-unit rise corresponded to an increase in dry matter yield of $500 \mathrm{~kg} / \mathrm{ha}$. In contrast to the spring LAI, the midsummer LAI had not reached its maximum whereas in the span of 35 days and with the temperature sum $=600^{\circ} \mathrm{C}$, the crop reached its maximum height. Both the protein content and DM cellulase digestibility reductions were steady during summer growth.

In the temperature range of $200-400^{\circ} \mathrm{C}$ every $10^{\circ} \mathrm{C}$ increase in cumulative temperature sum brought about a $0.1 \%$ unit and $0.4 \%$ units reduction in the protein content and cellulase digestibility respectively. At the same time each $10^{\circ} \mathrm{C}$ rise increased the dry matter content by $0.1 \%$.

The autumn LAI was initially almost as vigorous as the midsummer LAI in regard to growing period or temperature sum in degree days. In the 92 day growing period the autumn LAI approached a value of 8 . Usually in the autumn 
the LAI remains less than the early and late summer ones (AnsLow 1965 a and b). For fall growth an increase of LAI unit increased the dry matter yield by $315 \mathrm{~kg} \mathrm{ha}^{-1}$.

\section{3. Forage Yields and Quality}

\section{3.1. Dry matter content}

The total DM yield's dry matter content was, on the average, significantly higher during the production years for the 2-cut system than for the 3- and 4-cut systems (Table 9, Fig. 9). There were no significant differences between individual cuttings in regard to the dry matter contents for any of the cutting systems over the two year average (Fig. 10). Nitrogen fertilization decreased the DM yield's dry matter contents, even though a statistically significant difference was recorded actually for only the first production year. By checking each cutting system it was found that nitrogen reduced the dry matter content by a statistically significant amount only in the 4-cut system (Fig. 9). Nitrogen also had an effect on the individual cuttings' dry matter content only in the 4-cut system which had the most significant differences in its late summer cuttings (Fig. 10).

Seeding rate was significant at a low nitrogen level in the 2-cut system during the first actual production year in such a way than an increase in the seeding rate significantly increased the dry matter content (Table 9). The reason for this was the overdelayed cutting time resulting in overmaturity and a decrease in quality. The dry matter content proved to significantly decrease also when using the 4-cut system at a low level of nitrogen combined with the highest seeding rate (Fig. 10).
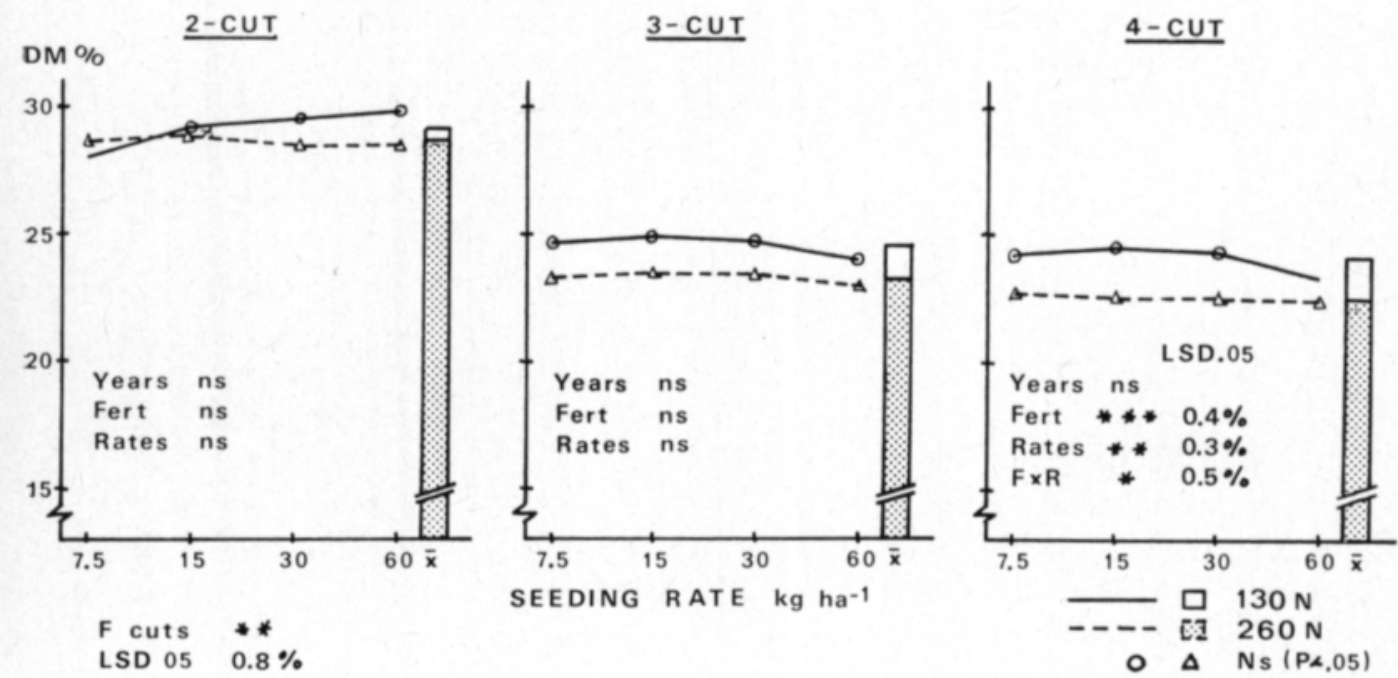

Fig. 9. Average dry matter content ( $\%$ DM) of three cutting systems at four population densities and two levels of nitrogen. 


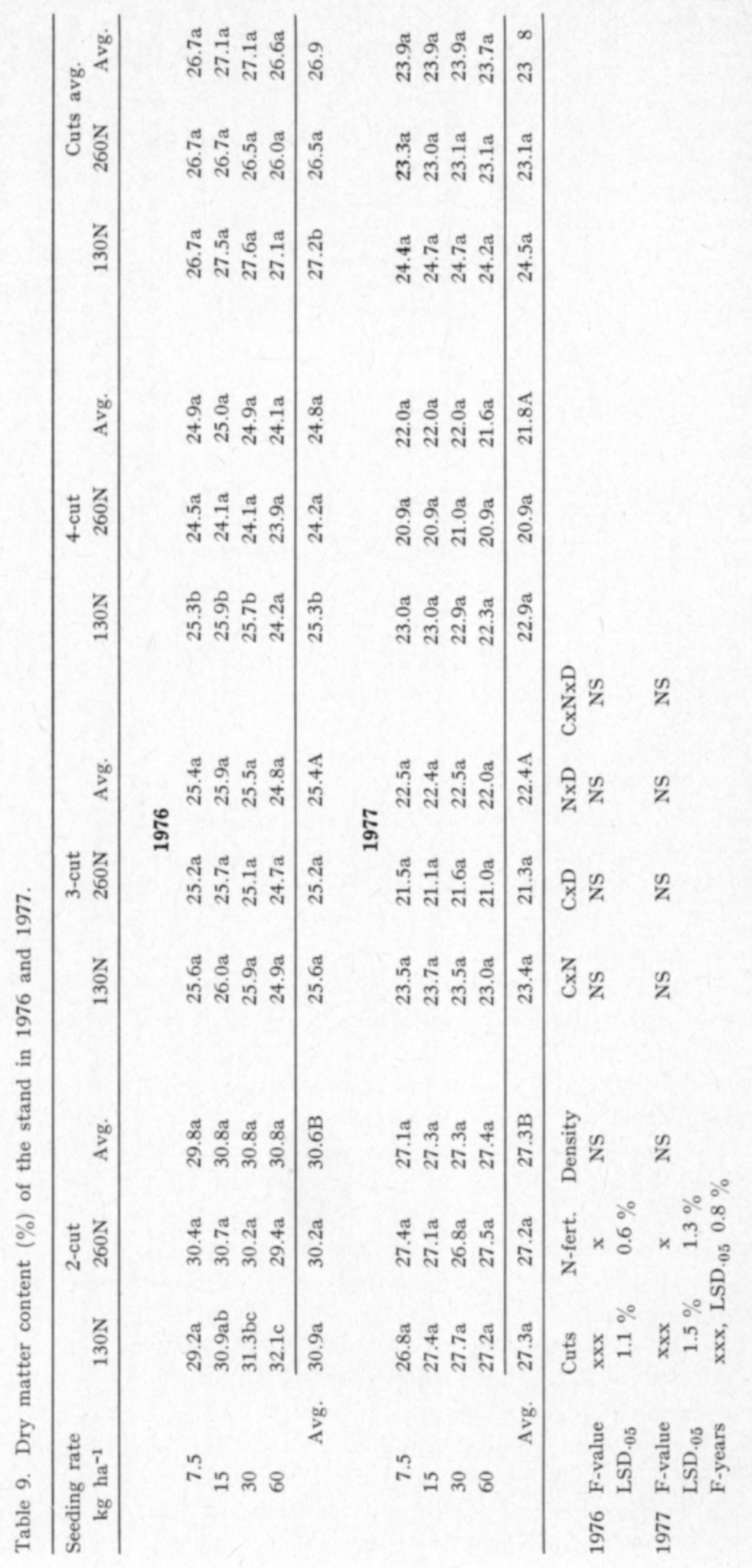



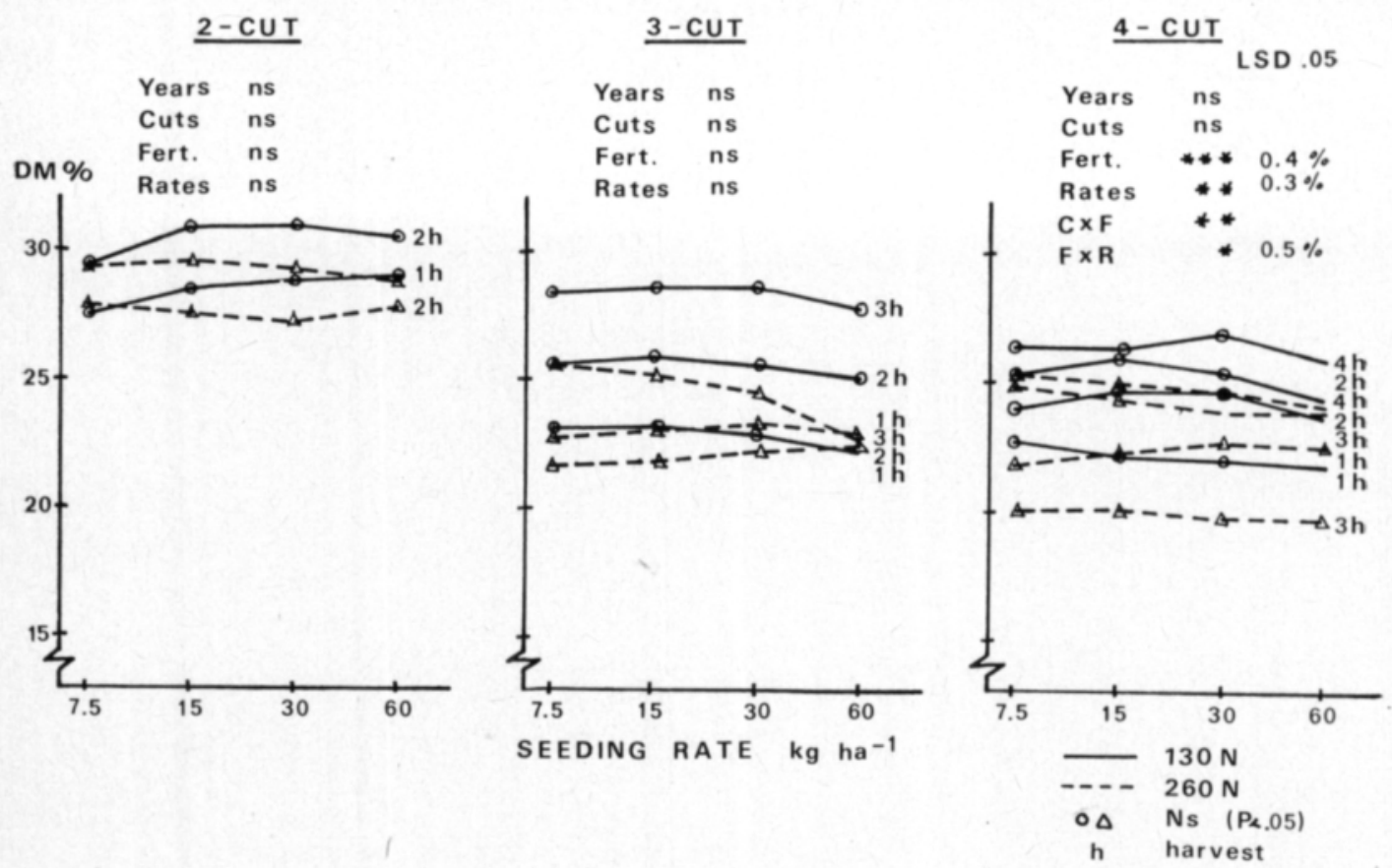

Fig. 10. Average dry matter content $(\% \mathrm{DM})$ of individual cuts in three cutting systems seeded at four population densities and ferilized at two levels of nitrogen.

\section{3. 2. Dry matter yields}

The dry matter yields for the seeding year average 4.4 tons $\mathrm{ha}^{-1}$, and for the two following production years 6.7 and 9.2 tons ha ${ }^{-1}$ respectively. The greatest dry matter yield was obtained by cutting twice and the smallest by cutting four times (Table 10). The differences between cutting systems were statistically significant for 1976 and 1977 (Table 10) and on the average for 1976-77 (Fig. 11). In the grand total yield for 1976-77 (Fig. 13) the yield level of the 4-cut system was significantly lower than yield level of the other cutting systems.

During the first cut of the 2-cut system two-thirds of the total yield for the growing period were obtained (Table 11). The 3-cut system produced the largest yields in the first cut and the smallest in the second in midsummer (Fig. 12). In the 4-cut system the smallest yield was obtained in the last cut (Table 11). On the average for $1976-77$ the largest part of the total yield came from the second cut of the 4-cut system, followed by the first and third cuts respectively. However, the cuttings did not statistically differ from each other (Fig. 12).

Nitrogen increased the dry matter yield significantly for all the cutting systems for 1976-77. The average increase in the grand total yield for 197677 , based on the nitrogen fertilizer change of $130 \mathrm{~kg} \mathrm{ha}^{-1}-260 \mathrm{~kg} \mathrm{ha}^{-1}$, was $2271 \mathrm{~kg} \mathrm{ha}^{-1}$ (Fig. 13). Adding nitrogen had the tendency of evening out the yield differences between cuttings in each cutting system. What was significant was that in the first cuttings there were no statistically significant differences such as those which showed up in later cuttings (Table 11, Fig. 12). 


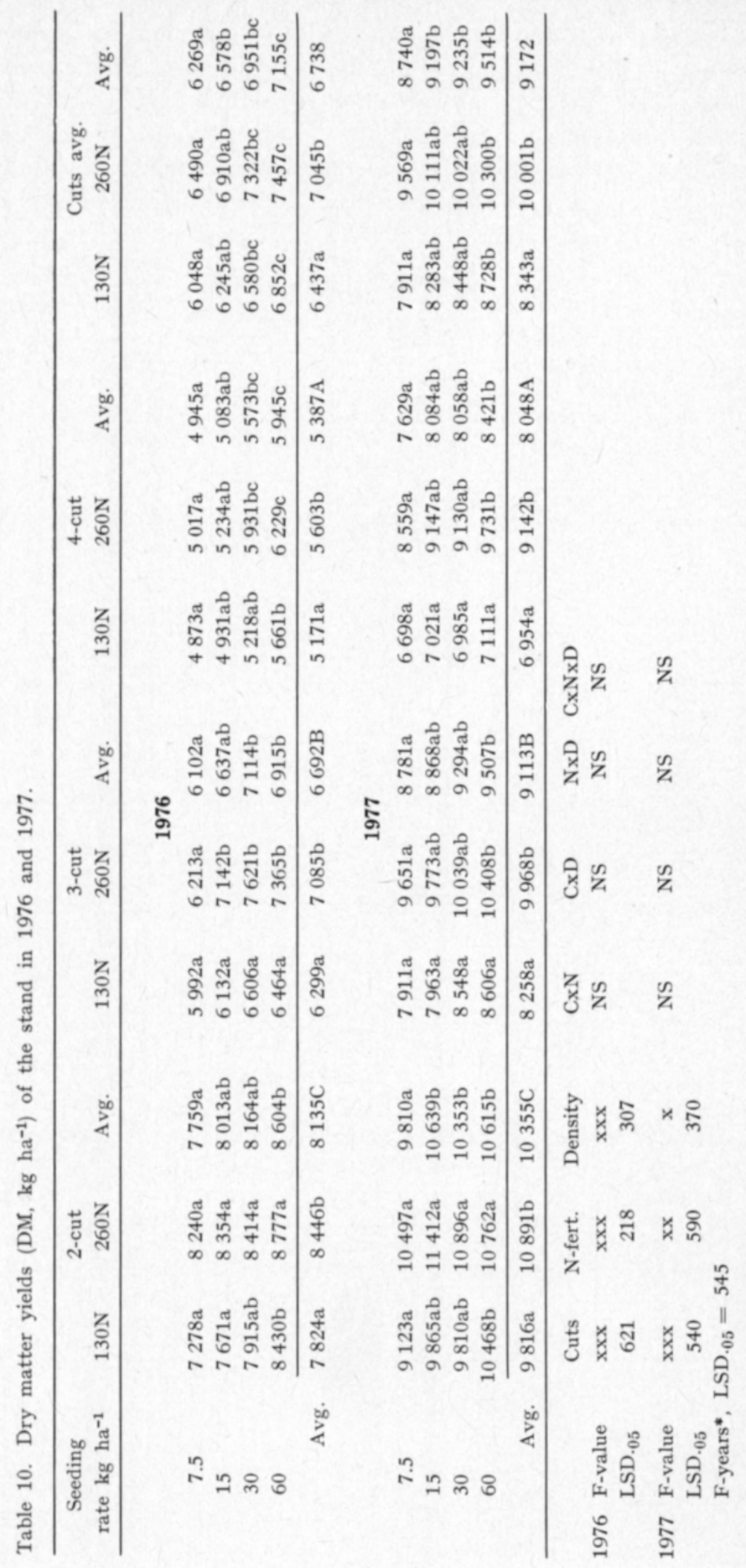


The yield level rose slightly with increases in the seeding rate from $7.5 \mathrm{~kg}$ $\mathrm{ha}^{-1}$ to the highest one of $60 \mathrm{~kg} \mathrm{ha}^{-1}$ (Fig. 9). However, the statistical maximum yield for the 2-cut system in both production years and, on the average, was achieved with the seeding rate of $15 \mathrm{~kg} \mathrm{ha}^{-1}$. At the higher nitrogen level the lowest seeding rate $\left(7.5 \mathrm{~kg} \mathrm{ha}^{-1}\right)$ was enough to obtain the statistical maximum yield, but on the average at the lower nitrogen level the highest seeding rate $\left(60 \mathrm{~kg} \mathrm{ha}^{-1}\right)$ was needed (Fig. 11).

Table 11. The relative proportions (\%) of individual cuts in the total dry matter yields in 1976-77.

\begin{tabular}{|c|c|c|c|c|}
\hline \multirow{2}{*}{ Cuttings } & \multicolumn{4}{|c|}{$\%$ of total yield } \\
\hline & & $130 \mathrm{~N}$ & $260 \mathrm{~N}$ & Avg. \\
\hline \multirow[t]{2}{*}{ 2-cut } & Cut 1. & 69.8 & 59.9 & 64.6 \\
\hline & Cut 2. & 30.2 & 40.1 & 35.4 \\
\hline \multirow[t]{3}{*}{ 3-cut } & Cut 1. & 54.1 & 42.0 & 47.6 \\
\hline & Cut 2. & 20.3 & 27.1 & 21.0 \\
\hline & Cut 3. & 25.6 & 36.3 & 31.4 \\
\hline \multirow[t]{4}{*}{4 cut } & Cut 1. & 31.9 & 24.4 & 27.8 \\
\hline & Cut 2. & 36.0 & 30.1 & 32.8 \\
\hline & Cut 3 . & 20.5 & 28.7 & 25.0 \\
\hline & Cut 4. & 11.6 & 16.8 & 14.4 \\
\hline
\end{tabular}
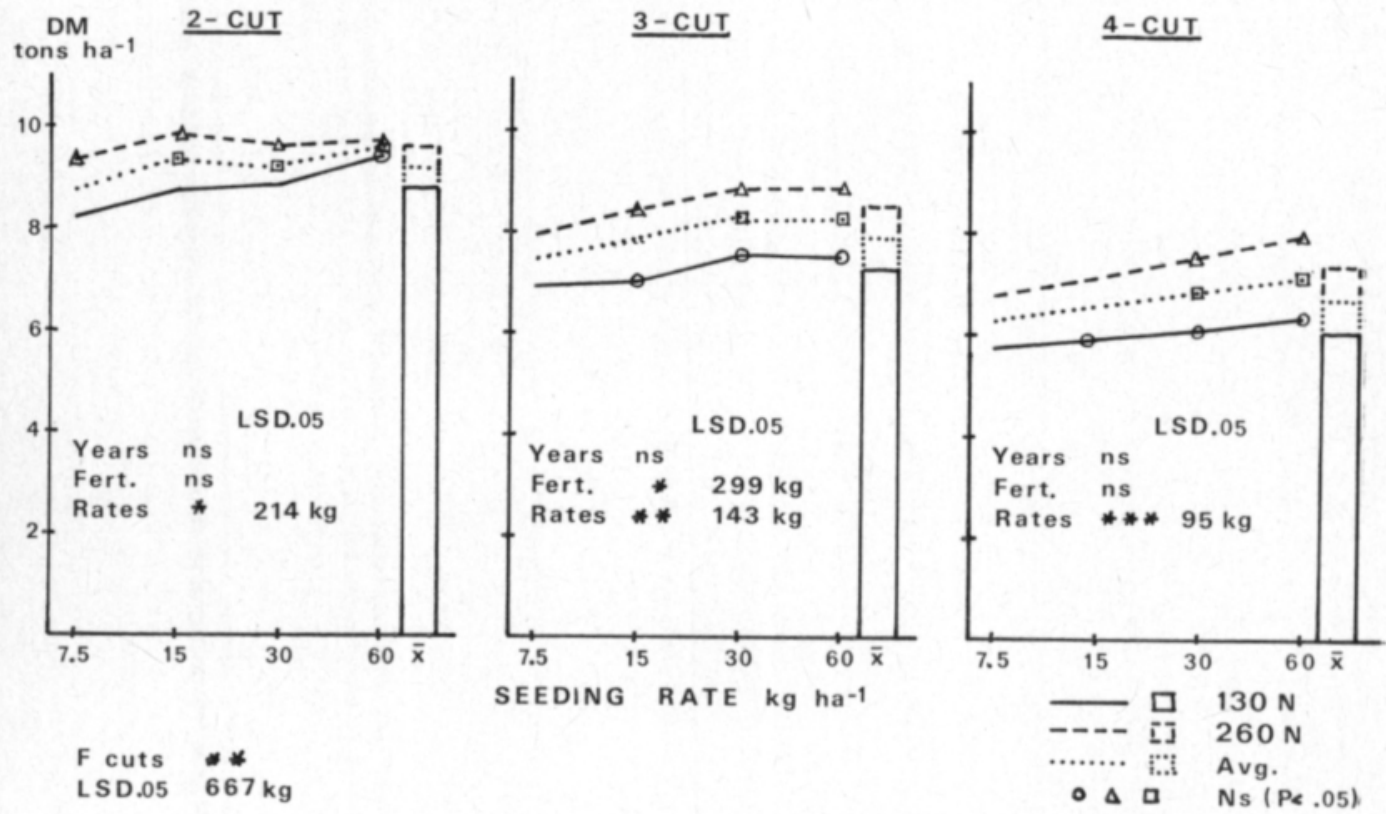

$\begin{array}{ll}\text { F cuts } & * * \\ \text { LSD.05 } & 667 \mathrm{~kg}\end{array}$

- $\Delta$

Fig. 11. Average dry matter yields (DM tons ha-1) of three cutting systems at four population densities and two levels of nitrogen. 


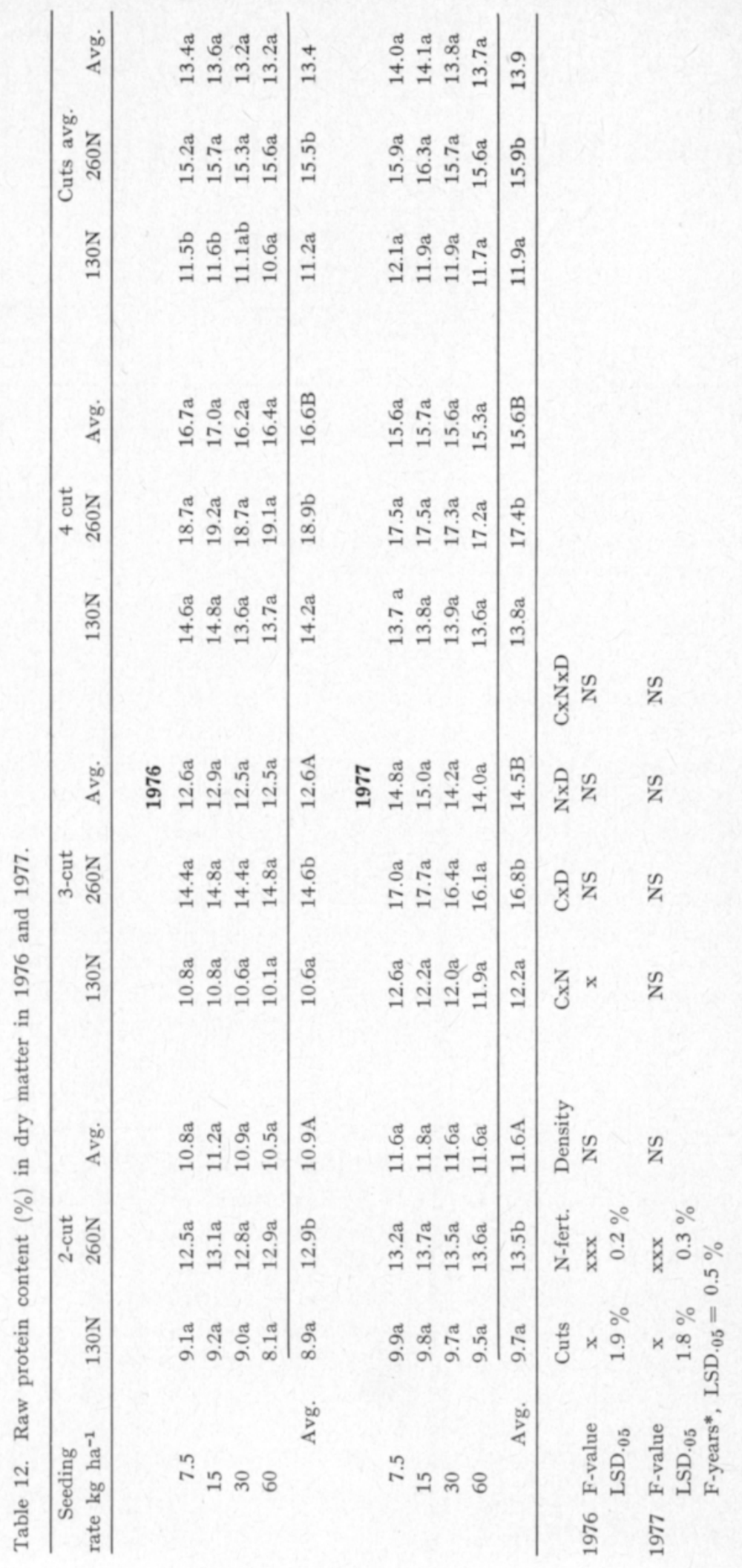




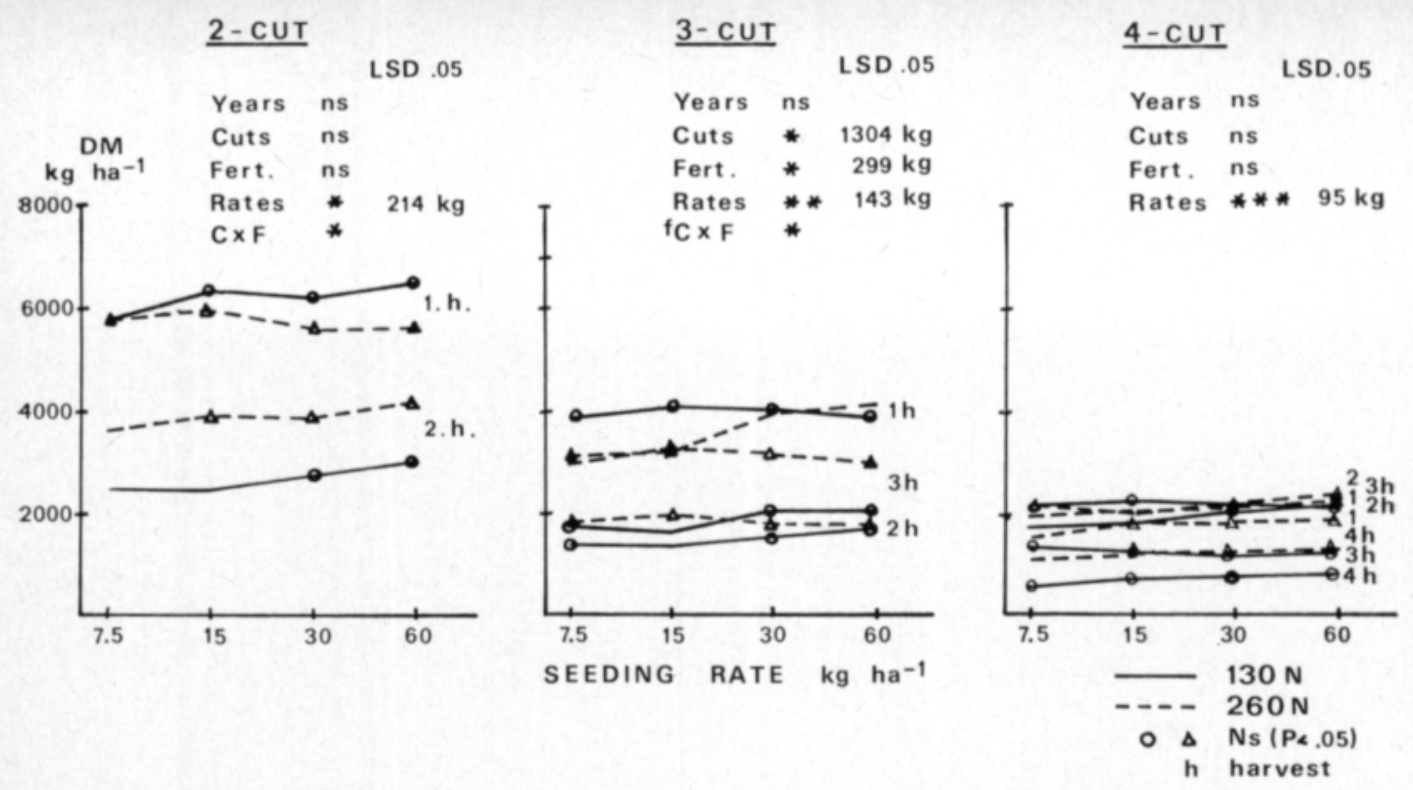

Fig. 12. Average dry matter yields (DM tons $\mathrm{ha}^{-1}$ ) of individual cuts in three cutting systems seeded at four population densities and two levels of nitrogen

For the 3-cut system the statistical maximum yield in both production years at the higher nitrogen level was got with the seeding rate of $15 \mathrm{~kg} \mathrm{ha}^{-1}$ (Table 10). At the lower nitrogen level the lowest seeding rate was sufficient for maximum yield. However, on the average the rate of $30 \mathrm{~kg}^{\mathrm{h}}{ }^{-1}$ was required for the statistical maximum yield in production years 1976-77.

In the 4-cut system the seeding rate had an especially significant influence on the yield. For the maximum yield in 1976 at the low level of nitrogen the seeding rate of $15 \mathrm{~kg} \mathrm{ha}^{-1}$ was needed and at the high level, $30 \mathrm{~kg} \mathrm{ha}^{-1}$. In the following year to achieve the coinciding maximum yield levels the seeding rates needed were: $7.5 \mathrm{~kg} \mathrm{ha}^{-1}$ and $15 \mathrm{~kg} \mathrm{ha}^{-1}$ (Table 10). On the average, the maximum yield for these years at the low level of nitrogen was reached with the seeding rate of $15 \mathrm{~kg} \mathrm{ha}^{-1}$, and at the high level with $30 \mathrm{~kg} \mathrm{ha}^{-1}$ (Fig. 11).

\subsection{Raw protein content of dry matter}

The protein content of the total dry matter yields was highest in both years in the 4-cut system and lowest in the 2-cut one (Table 12). On the average for 1976-77 the differences in protein content between all cutting systems were statistically significant (Fig.14).

In 1976-77 the differences between cuttings regarding protein content in the 2-cut system favored the fall cutting by $1.3 \%$ units. The difference was not statistically significant (Fig. 15). In the 3-cut system the highest protein content was obtained in the second cutting and the lowest in the fall cutting. However, the differences were not statistically significant. There were no statistical differences between the cuttings of the 4-cut system during 1976-77, although, if ranked according to results they would be first, third, fourth and second cutting. 

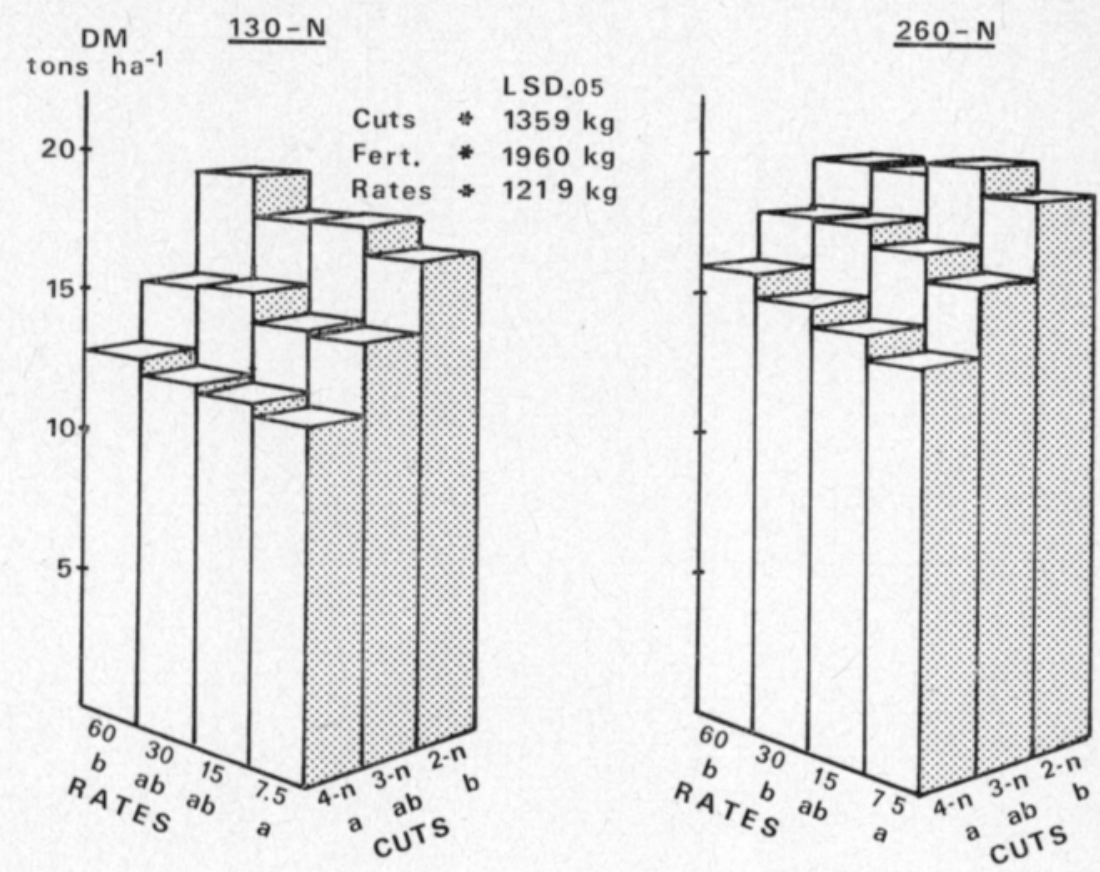

Fig. 13. Total dry matter yields (DM tons ha ${ }^{-1}$ ) in $1976-77$ of three cutting systems seeded at four population densities and fertilized at two levels of nitrogen.

Nitrogen fertilizer raised the protein content by 4.1 percentage units on the average; a very significant amount. The addition of nitrogen fertilizer produced average increases of $3.9,4.3$ and 4.2 percentage units in the 2-, 3 - and 4-cut systems respectively.

For 1976 it was observed that the fertilizer's and cuttings' combined effect was such that additional nitrogen increased the protein content in the second cutting of the 2-cut system and in the third cuttings of both the 3-and 4-cut systems. The seeding rate had very little significance for the protein content of the dry matter yield.

\section{3. 4. Raw protein yields}

In 1976 (the year after seeding), all three cutting systems produced close to the same amount of protein per unit of surface area. In 1977 statistically significant differences occurred between all of the cutting systems. On the average for $1976-77$, protein yield differences were not observed, 2-cut system, $1052 \mathrm{~kg} \mathrm{ha}^{-1}$, 3-cut system, $1097 \mathrm{~kg} \mathrm{ha}^{-1}$, 4-cut system, $1086 \mathrm{~kg} \mathrm{ha}^{-1}$ (Table 13). Also in the grand total yield for $1976-77$ there were no statis tically significant differences between the cutting systems (Fig. 16).

Nitrogen fertilizer increased the protein yield by an average of 364,608 and $486 \mathrm{~kg} \mathrm{ha}^{-1}$ for 1976,1977 and $1976-77$ respectively. The amount of the $1976-77$ combined protein yield was influenced very significantly $(P=0.001)$ by the nitrogen fertilizer. 


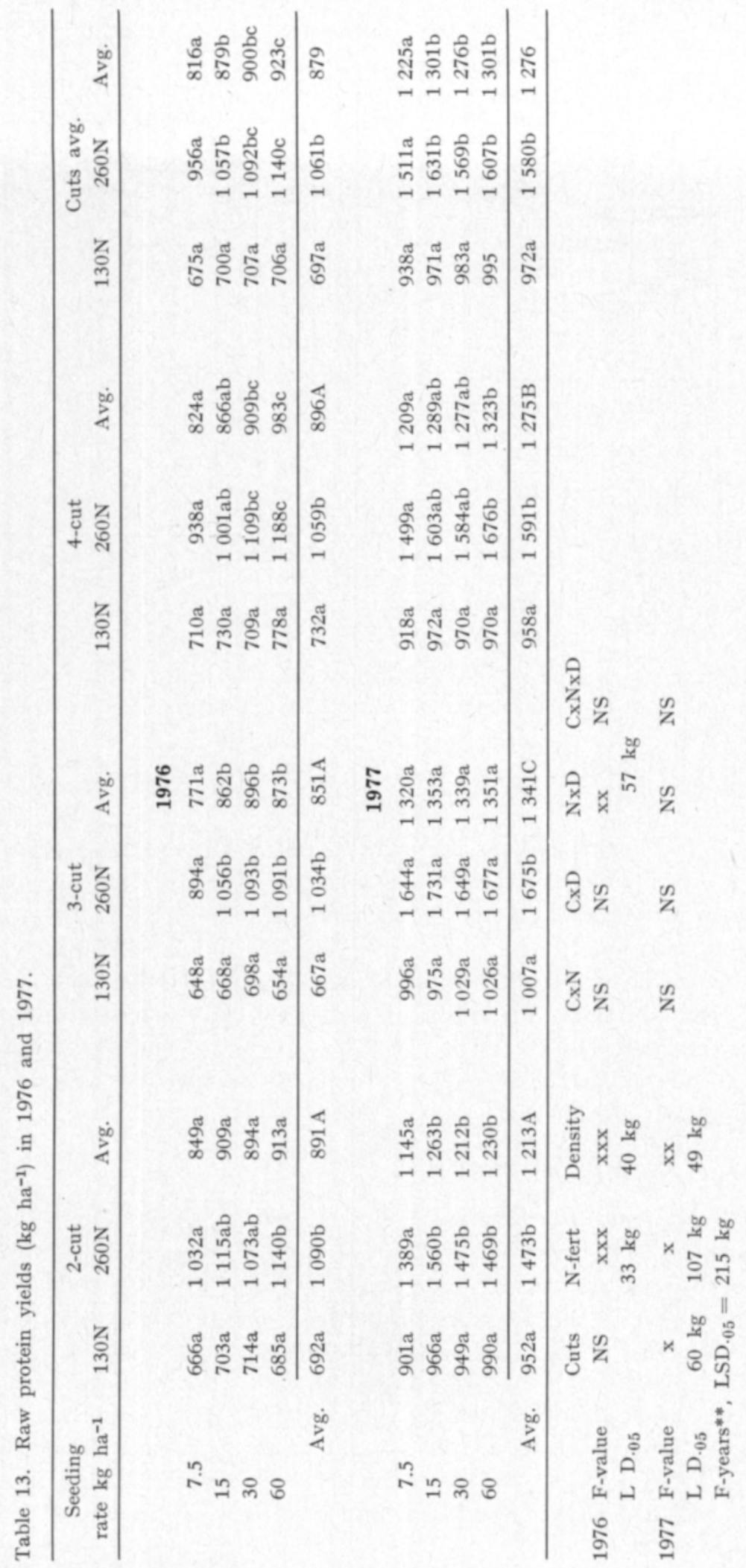




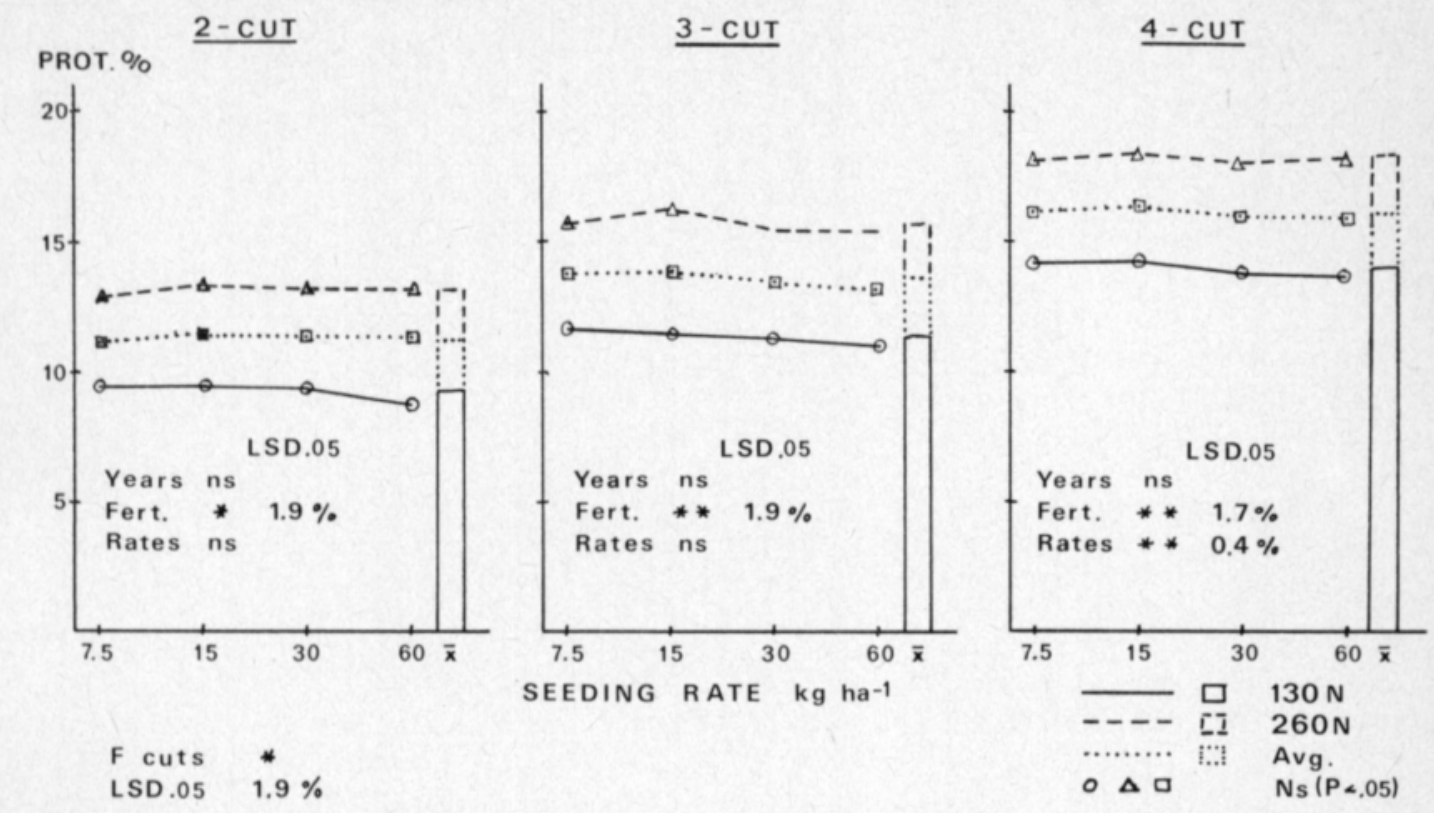

Fig. 14. Average protein content (prot. \% in DM) of three cutting systems at four population densities and two levels of nitrogen.

\section{2-CUT}

PROT. \%

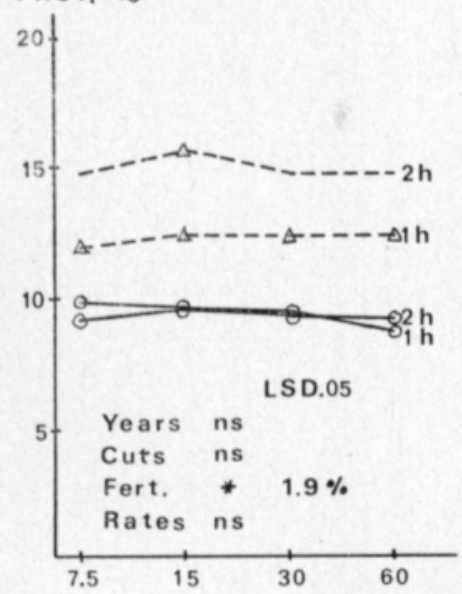

$\underline{3-C U T}$

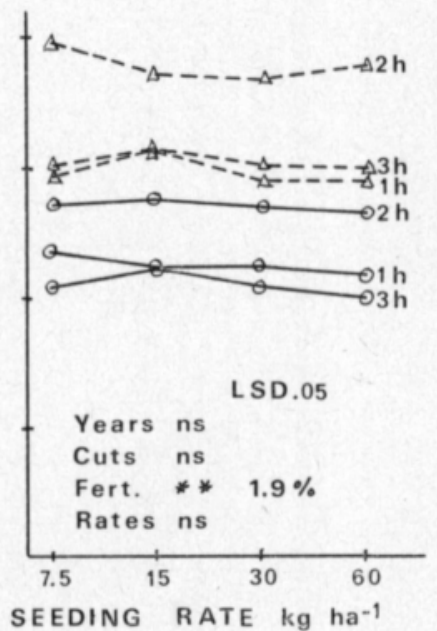

\section{4-CUT}

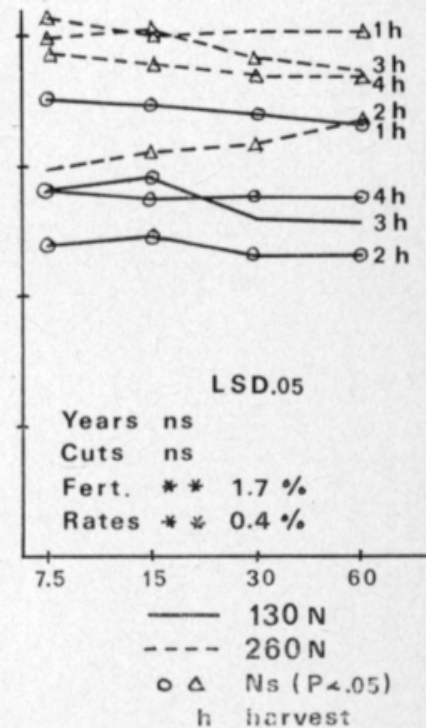

Fig. 15. Average protein content (prot. \% in DM) of individual cuts in three cutting systems seeded at four population densities and fertilized at two levels of nitrogen. 


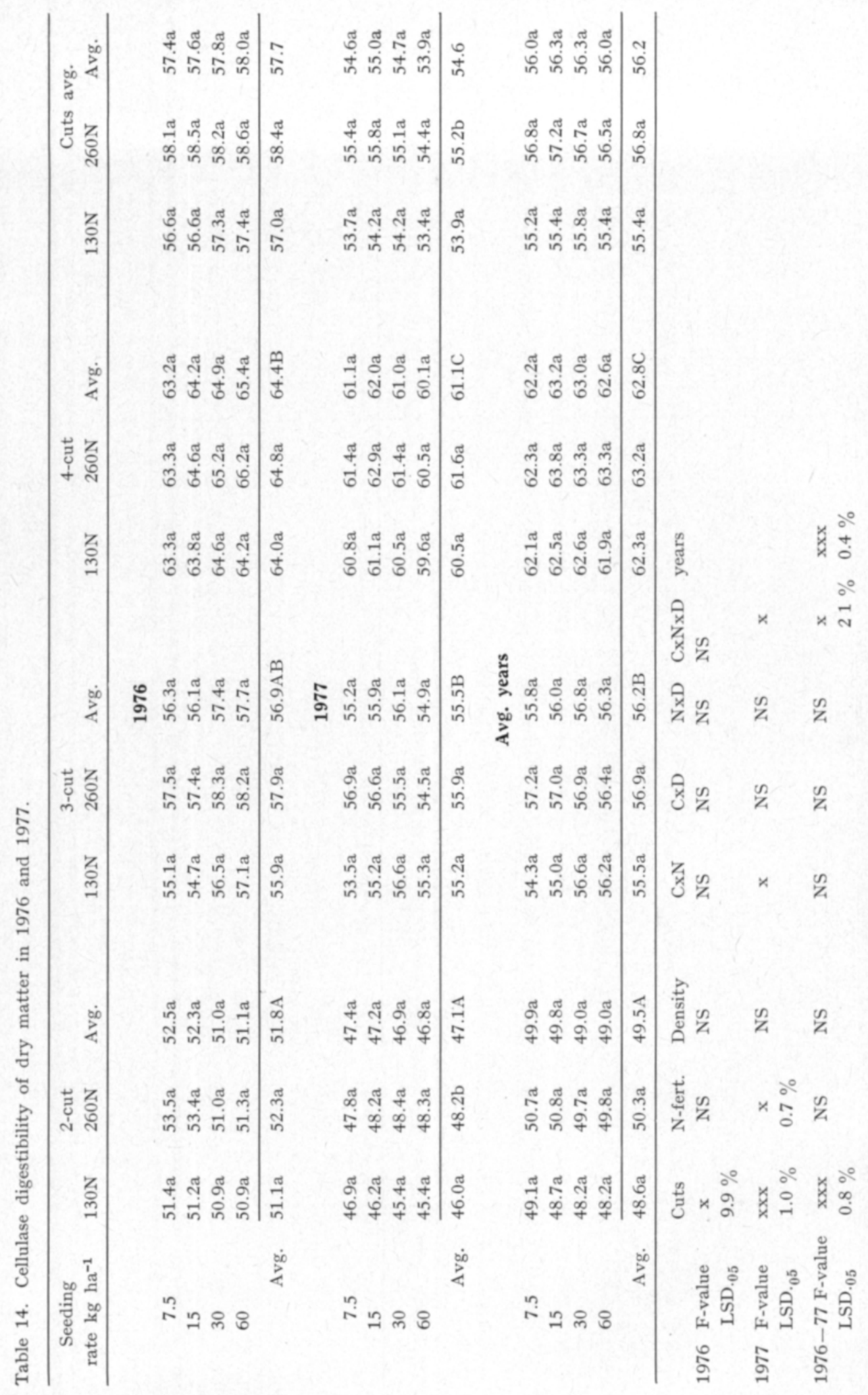




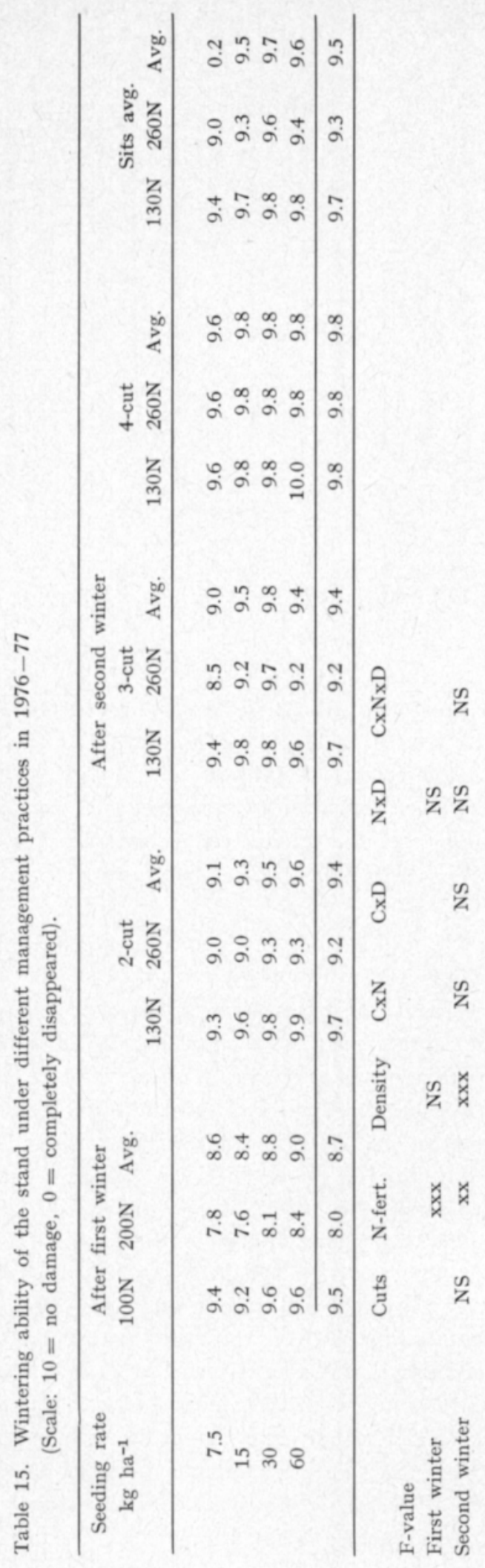



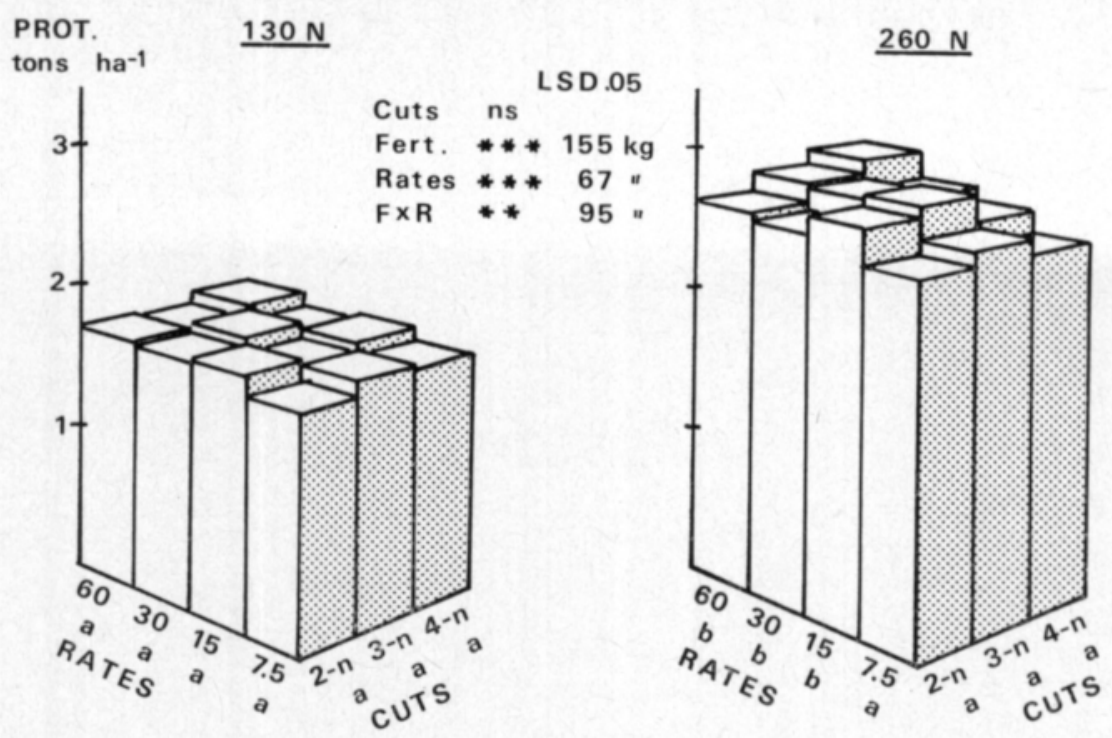

Fig. 16. Total protein yields (prot. tons ha $\mathrm{h}^{-1}$ ) in $1976-77$ of three cutting systems seeded at four population densities and fertilized at two levels of nitrogen.

In 1976 the maximum protein yield was achieved with a seeding rate of $30 \mathrm{~kg} \mathrm{ha}^{-1}$, and in 1977 with $15 \mathrm{~kg} \mathrm{ha}^{-1}$ (Table 13). At the low nitrogen level the seeding rate had no effect on the protein yield in any of the cutting systems. At the high nitrogen level the minimum seeding rate was not sufficient for reaching the maximum protein yield in the 2 - and 4 -cut systems. This same trend was found for all cutting systems at the high nitrogen level in the grand total yield (Fig. 16).

\subsubsection{Cellulase digestibility of dry matter}

The highest DM cellulase digestibility in both years was in the 4-cut system and the lowest in the 2-cut system. During 1976-77 all of the cutting systems differed from each other with very high significance (Table 14).

Differences between the invidual cuts of the cutting systems were found only in the 4-cut system (Fig. 17), where the highest digestibility in both years was in the first cutting and the lowest in the second.

Nitrogen fertilizer raised the dry matter's digestibility in 1976 and 1977, but a significant change was registered only for 1977 . In 1977 also the combined effect $(\mathrm{CxN})$ was significant, where the nitrogen fertilizer significantly raised the cellulase digestibility in the 2-cut system, but not in the 3- or 4-cut systems.

On the whole, the seeding rate had no statistically significant influence on the dry matter's cellulase digestibility in either year. From forage samples a part of the dry matter's digestibility in vitro was also determined. There was a very significant correlation between the cellulase digestibility and the in vitro digestibility (Fig. 18). The dependence between cellulase and in vitro digestibility determined for fescue corresponds well to correlations for clovergrass mixture and coach grass (Pulli 1976). 

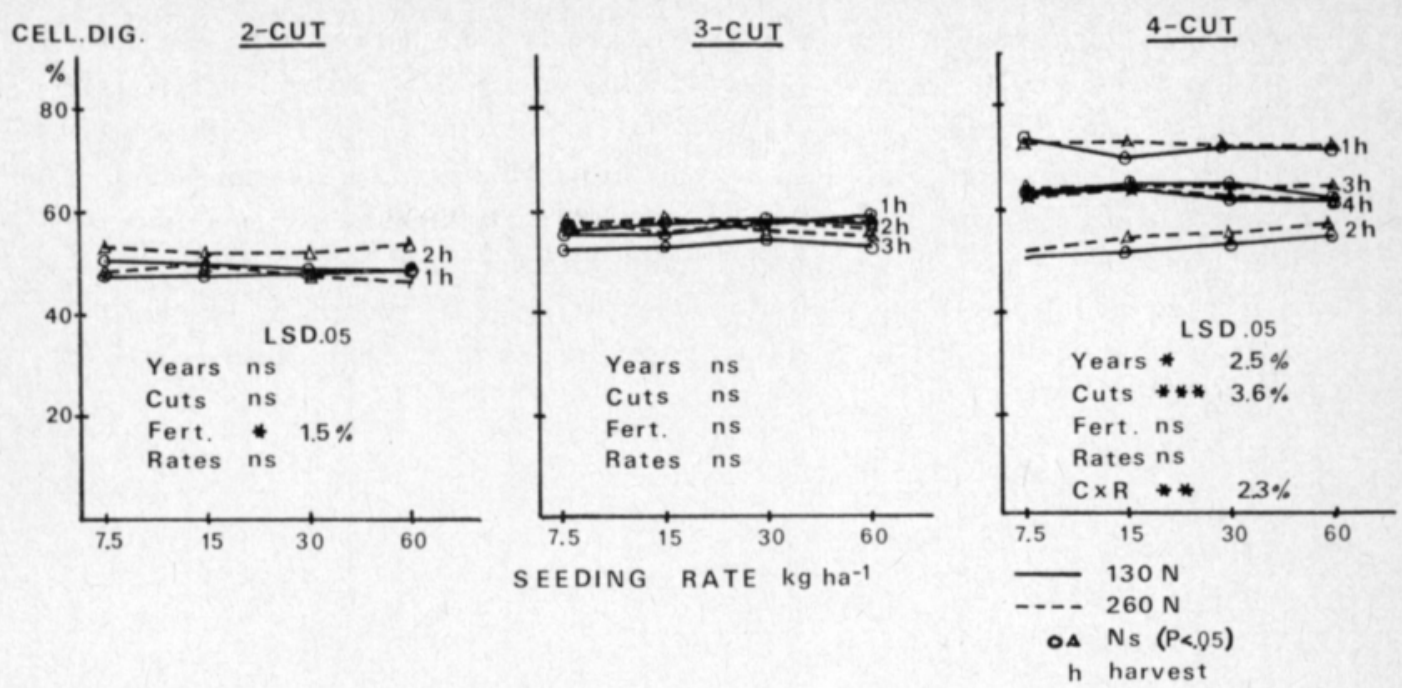

Fig. 17. Dry matter cellulase digestibility $(\%)$ of individual cuts in three cutting systems seeded at four population densities and fertilized at two levels of nitrogen.

\section{3. 6. Discussion}

Number of cuttings

An increase in the number of cuttings means a per cutting and per growing season decrease in dry matter yield (CARTER and LAw 1948, HuOKuna 1957, Brougham 1959, Heinrichs and Crark 1961, Laine 1965, Anslow 1967, Frame and Hunt 1971, Pedersen et al. 1974, Wolton 1976).

In this investigation significantly larger yields were gained with two cuttings as compared to three or four. A reduction in the number of cuttings, however, meant a noticeable drop in the quality of the yield, as described by high dry matter content, low protein content and low cellulase DM digestibility.

Instead, the number of cuttings showed, as in prior investigations (SAGLAMtimur and Bogdan 1970, LAWrence et al. 1971), that it had little influence on the protein yield per unit of area.

Diffirences in quality between cuttings were least in the 2- and 3-cut systems. The highest protein content and digestibility were with the 4-cut system, which also provided the most balanced yield per cutting because the early summer's rapid growth covered two cuttings. Dividing the fast growth phase between two cuttings means a reduction in the total yield (HUOKUNA 1964). The amount of the yield and its quality are tied by correlations to the different cutting systems. The distribution of the yields between different cuttings as is done in the cutting systems, affects the forage quality the most decisively.

\section{Nitrogen fertilization}

The increasing application of nitrogen fertilizer from 130 to $260 \mathrm{~kg} \mathrm{ha}^{-1}$ raised the dry matter yield by an average of $1110 \mathrm{~kg} \mathrm{ha}^{-1}$ in $1976-77$. One kilogram of nitrogen between the range $130-260 \mathrm{~kg} \mathrm{~N} \mathrm{ha}^{-1}$ produced a dry 
matter yield increase of $8.5 \mathrm{~kg}$. The yield increases obtained corresponded with previous investigations (LAINe 1966, Hirvola et al. 1974, Rinne 1971).

Nitrogen fertilization improves the quality of the yield. The fertilizer reduced the dry matter content in all cutting systems, but only significantly in 4-cut system. Increasing the nitrogen from $130 \mathrm{~kg}$ to $260 \mathrm{ha}^{-1}$ correspondingly raised the forage's protein content by 4.2 percentage units, or in other words an average of 0.3 percentage units for every $10 \mathrm{~kg} \mathrm{~N} \mathrm{ha}^{-1}$ increase. The corres pondent increase in protein yield was $485 \mathrm{ha}^{-1}$, which agrees with Hirvola et al. (1974).

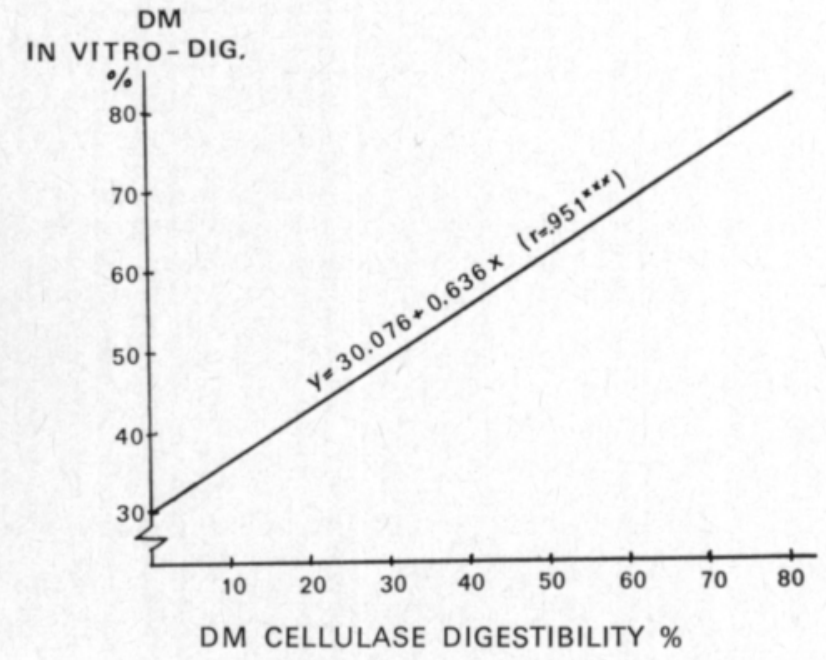

Fig. 18. The relationship between the dry matter cellulase digestibility and the dry matter in vitro digestibility of meadow fesque (Festuca pratensis) stand at different stages of maturity.

At the low nitrogen level the protein yield ranged from $667 \mathrm{~kg}$ to $1007 \mathrm{~kg}$, and at the high level from $1034 \mathrm{~kg}$ to $1675 \mathrm{~kg}$ for all cutting systems. On the average the low nitrogen level produced $835 \mathrm{~kg} \mathrm{ha}^{-1}$ of protein and the high level $1320 \mathrm{~kg} \mathrm{ha}^{-1}$, resulting in $3.7 \mathrm{~kg}$ of protein for every $\mathrm{kg}$ of nitrogen between the nitrogen levels of $130-260 \mathrm{~kg} \mathrm{~N} \mathrm{ha}^{-1}$.

Nitrogen had the least effect on the dry matter digestibility in the $4^{-}$cut system and the best in the 2 -cut system. The $\mathrm{N}$-fertilizer raised the dry matter cellulase digestibility an average of 1.4 percentage units. According to STEEN (1972), nitrogen fertilizer improves mostly protein digestibility.

\section{Population density effects}

During the first year the densest stand is the most productive, but in the following years the highest yields are obtained from the less dense stands (Donald 1956). A corresponding phenomena was observed in this investigation. In the seeding year the greatest yield was achieved with the seeding rate of $60 \mathrm{~kg} \mathrm{ha}^{-1}\left(2600\right.$ seeds $\left.\mathrm{m}^{-2}\right)$. During the first actual production year the statistical maximum was achieved with the rate of $30 \mathrm{~kg} \mathrm{ha}^{-1}\left(1300\right.$ seeds $\left.\mathrm{m}^{-2}\right)$ at both nitrogen levels. In the second production year the maximum yield required only a seeding rate of $15 \mathrm{~kg} \mathrm{ha}^{-1}\left(650\right.$ seeds $\left.\mathrm{m}^{-2}\right)$. These results agree 

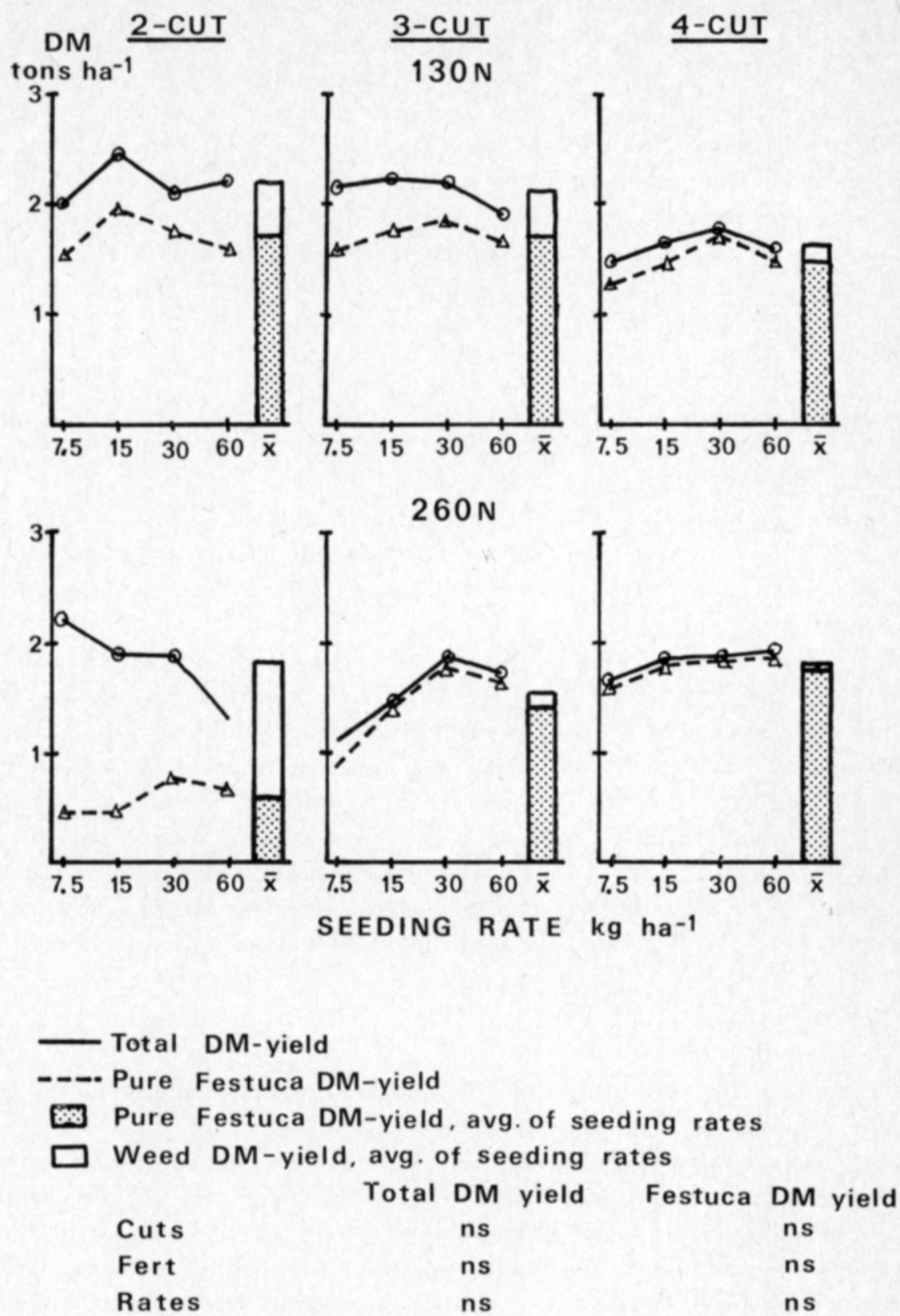

Fig. 19. The management post effects on the total and pure meadow fesque yield three years after seeding.

well with the results of LAINE (1958) and Järvi (1977). As LAINE (1958) showed, the third year's statistical maximum yield was achieved with the rate of $7.5 \mathrm{~kg}$ $\mathrm{ha}^{-1}$ (Fig. 19). In general it was so that with an increase in the number of cuttings the statistical maximum yield required a slightly larger rate of seeding. The exception was the 2-cut system, where delaying the first cutting created competition at high growing densities which in turn raised the dry matter 
content so much that the yield level sharply climbed all the way to the levels characteristic for the highest seeding rates. This phenomena was noticeable particularly at the low level of nitrogen. Applying nitrogen as experienced by Donald (1951) and Norrington and Davies (1969) increased the seeding rate requirements for the maximum yield.

The seeding rate had very little influence on the quality of the yield, and did not affect either dry matter content or cellulase digestibility at all. Increasing the seeding rate reduced the protein content very little as compared to the findings of van Burg (1962) and Alberda (1965 a).

\section{4. Management Post Effects}

\section{4. 1. Wintering}

The seeding rate and the nitrogen fertilizer applied in the seeding year influenced the wintering that followed the seeding year. In spring 1977 an influencing factor, in addition to the previous factors, was also the cutting frequency.

Obervations showed (Table 15) that the nitrogen fertilization had the greatest effect on wintering in both years. The application of $100 \mathrm{~kg} \mathrm{~N} \mathrm{ha-1}$ did not thin the crop at all, whereas the application of $200 \mathrm{~kg} \mathrm{~N} \mathrm{ha}^{-1}$ thinned the stands at all densities. The most severe decrease in plant density occurred in the stand with the lower seeding rate. The influence of nitrogen fertilizer during the second winter was less than that for the seeding year, but still statistically significant. The stand was thinned most when cut twice at the high level of nitrogen. When cutting four times, the nitrogen fertilizer had the least negative effect on wintering. A statistically significant combined effect $(\mathrm{CxN})$ was not observed.

\section{4. 2. Productivity}

To establish the post effects of the treatments, all plots received $75 \mathrm{~kg} \mathrm{~N}$ $\mathrm{ha}^{-1}$ and were cut at the same time in the spring of 1978.

At the low level of nitrogen the total dry matter yield decreased with an increase in the number of cuttings (Fig. 19). At the high levels of nitrogen this trend was milder. The lower nitrogen level produced $253 \mathrm{~kg} \mathrm{ha}^{-1}$ more dry matter than the high one. More regrowth, in addition, was found if the cutting frequency or nitrogen level was raised with one exeption being the 2-cut system with the low level of nitrogen. In the 4-cut system fescue comprised $93.7 \%$ of the total yield and in the 2-cut system only $56.2 \%$. The most stressing treatment was the 2-cut system at a high level of nitrogen and at low rate of seeding.

\section{4. 3. Discussion}

The disruptive effects of a high level of nitrogen begin to manifest themselves in the yield development and in the wintering of the stand (HUOKUNA and Hirvola 1974). According to this investigation the application of $100 \mathrm{~kg} \mathrm{~N}$ $\mathrm{ha}^{-1}$ in the second cutting during the seeding year damaged wintering stands. 
During the second winter the nitrogen fertilizer did not have a decisive effect in any of the cutting systems. It can be seen from the regrowth, however, that in the 2-cut system the $130 \mathrm{~kg} \mathrm{~N} \mathrm{ha}^{-1}$ application per cutting was too much for fescue survival. In accordance with previous studies (HUOKUNA 1974, HaKKola 1978) when increasing the cutting frequency at a certain level of nitrogen, the amount of nitrogen per cutting decreases and the stand survival improves.

\section{Summary and conclusions}

The investigation of meadow fescue was carried out at the University of Helsinki in Viikki in 1975-78. The main objective was to study the rhythm of the growth and yield formation pattern of a forage crop and the relationship between growth pattern and growth factors during different phases of the growing season. The management techniques studied were the number of cuttings, use of nitrogen, requirements of population density and the relationships of management factors to the changes in the quantity and quality of forage yield. The following results have been drawn:

1. The most important factors concerning the LAI and height increase of spring growth in the seeding year were the temperature sum in degree days and the total radiation. The seeding year's fall LAI and height correlated weakly to the growing time and temperature sum. The late summer height growth during the seeding year was significantly influenced by nitrogen fertilizer beyond the temperature sum range of $500^{\circ} \mathrm{C}$.

2. Differences in growing densities based on seeding rates disappeared in the dry growing conditions eight weeks after seeding. However the seeding year yield level can be raised with increasing population density.

3. During the production years after the seeding year the most important yield formation variables during spring growth were the growing time, the temperature sum in degree days and the total radiation. For midsummer and fall growth the following determinants described growth the best: precipitation, amount of nitrogen for the cut and the precipitation during the week before the prior cut.

4. During spring growth at a temperature sum of $750^{\circ} \mathrm{C}$ the yield level obtained was 6 tons ha $^{-1}$ with the following quality characteristics: dry matter content $30 \%$, protein content $10 \%$ and cellulase digestibility of dry matter $50 \%$. The summer growth yield level at a temperature sum of $700^{\circ} \mathrm{C}$ was 4 tons $\mathrm{ha}^{-1}$ with the characteristics: dry matter content $22 \%$, protein content $17.5 \%$ and cellulase digestibility of dry matter $55 \%$. The fall growth temperature sum contains the second cutting of the 2-cut system. For the fall growth with the temperature sum of $1200^{\circ} \mathrm{C}$ the obtained dry matter yield was 3.5 tons $\mathrm{ha}^{-1}$ and had quality characteristics of: dry matter content $29 \%$, protein content $12 \%$ and cellulase digestibility of dry matter $50 \%$.

5. During midsummer and fall the crop's development was noticeably slower than in the spring. At this time the quality of the yield remained considerably steady, as the dry matter increase and the protein content decrease 
were slight. For spring growth the dry matter content rise and protein content decrease were sharp in the temperature sum range of $150-350^{\circ} \mathrm{C}$. The decrease in cellulase digestibility was strongest in the temperature sum range of $250-$ $650^{\circ} \mathrm{C}$.

6. A very significant correlation between dry matter yield and LAI existed throughout the growing period. The spring growth's maximum LAI was 8.5, which represents a temperature sum of $550^{\circ} \mathrm{C}$. The summer and fall growths' LAI value of 7.5 represents temperature sums of 700 and $1200^{\circ}$ respectively. For spring, summer and fall growth a one unit increase in LAI created a dry matter yield increase of 715,500 and $315 \mathrm{~kg} \mathrm{ha}^{-1}$ respectively. The corresponding heights for the spring and summer periods were $85 \mathrm{sm}, 60 \mathrm{~cm}$. Because of height growth differences a smaller and smaller dry matter yield is obtained in the autumn at the same LAI value.

7. An increase in the number of cuttings signifies a smaller yield per cutting and per growing season but a considerable improvement in the quality of the yield. Increasing the number of cuttings from two to four decreased the yield by and average of $2527 \mathrm{~kg} \mathrm{ha}^{-1}$. At the same time the protein content and dry matter cellulase digestibility increased an average of 4.8 and 13.3 percentage units respectively.

8. Increasing the nitrogen fertilizer applications from 130 to $260 \mathrm{~kg} \mathrm{~N} \mathrm{ha}^{-1}$ raised the dry matter yield by $1110 \mathrm{~kg} \mathrm{ha}^{-1}$, the protein yield by $485 \mathrm{~kg} \mathrm{ha}^{-1}$, the protein content by 4.2 percentage units and the cellulase digestibility by 1.4 units.

9. The influence of growing density on yield formation was more significant the more often the crop was cut. The seeding year's greatest dry matter yield was obtained with a seeding rate of $60 \mathrm{~kg} \mathrm{ha}^{-1}$. During the following growing season $15 \mathrm{~kg} \mathrm{ha}^{-1}$ were needed to produce the greatest yield in the 2- and 3 cut systems and $30 \mathrm{~kg} \mathrm{ha}^{-1}$ for the 4-cut system. In the third growing season $15 \mathrm{~kg} \mathrm{ha}^{-1}$ produced the maximum dry matter yield in all cutting systems. To achieve the maximum yield a higher population density is needed if nitrogen fertilizer and the number of cuttings are increased. Not including the seeding year, the seeding rate had little effect on the yield's quality. In the fourth growing season the seeding rate had no statistical effect.

10. In the seeding year's fall growth and in the 2-cut system, 100 and $130 \mathrm{~kg} \mathrm{~N} \mathrm{ha}{ }^{-1}$ respectively were too stressing for the stands. In regard to preservation of the crop's productivity, the yield quantity and quality, a management system involving a seed amount of $30 \mathrm{~kg} \mathrm{ha}^{-1}, 3-4$ cuttings per growing season and a fertilization level of $260 \mathrm{~kg} \mathrm{~N} \mathrm{ha}^{-1}$ is recommended as the best. 


\section{REFERENCES}

Agerberg, L. S. 1943. Slåttertids- och gödslingsförsök i vall. Lantbr.högsk. Jordbr.anst. Medd. 9: 1-45.

- 1956. Slåttertid och hökvalitet. Stat. Jordbr.förs. Medd. 72:1-46.

AlBerdA, Th. 1965 a. The influence of temperature, light intensity and nitrate concentration on dry matter production and chemical composition of Lolium perenne L. Neth. J. Agric. Sci. 13: 335-360.

- $1965 \mathrm{~b}$. The problems of relating greenhouse and controlled environmental work to sward conditions. J. Brit. Grassl. Soc. 20:41-48.

AnsLow, R. C. 1965 a. Grass growth in midsummer. J. Brit. Grassl. Soc. 20: 19-26.

- 1965 b. Light interception and growth rate of a perennial ryegrass sward. Proc. 9th Int. Grassl. Gongr. Sao Paolo. p. 403-405.

- 1967. Frequency of cutting and sward production. J. Agric. Sci. Camb. 68: 377-384.

Antılı, S. 1975. Valkuaispitoisempaa nurmirehua. Käytännön Maamies 1975, 9: 14-15.

Antrinen, O. 1961. Italian raiheinän typpilannoituksesta. Koetoim. ja Käyt. 18: 9.

BAERUNG, R. 1977 a. Nitrogen, kalium magnesium og svovel til eng på Sor-Ostlandet. 1. Avlinger og jordanalyser. Forsk.fors. Landbr. 28: 533-548.

- 1977 b. Nitrogen, kalium, magnesium og svovel til eng på Sør-Østlandet. 2. Kjemiske analyser av avlingen. Forskn.fors. Landbr. 28: 549-574.

Baeumer, K. 1964. Konkurrenz in Pflanzenständen als Problem der Pflanzenbauforschung. Forchung und Beratung B 10: 99-123.

_ \& WrT, C. T. de. 1968. Competive interference of plant monocultures and mixtured stands. Noth. J. Agric. Sci. 16: 103-122.

BAKER, H. K. 1957. Studies on the root development of herbage plants. 2. The effect of cutting on the root and stubble development, and herbage production of spaced perennial ryegrass plants. J. Brit. Grassl. Soc. 12: 116-126.

- Garwood, E. A. 1959. Studies on the root development of herbage plants. 4. Seasonal changes in the root and stubble weights of various leys. J. Brit. Grassl. Soc. 14: $94-104$.

Blacкman, G. E. 1968. The application of the concepts of growth analysis to the assesment of productivity. Function of Terrestial Ecosystems at the Primary Production Level. p. 243-259. Ed. Eckardt, F. E. UNESCO, Paris.

Braun-Blanguet, J. 1964. Pflanzensoziologie. 865 p. Wien.

Brougham, R. W. 1958. Interception of light by the foliage of pure and mixed stands of pasture plants. Austr. J. Agric. Res. 9: 39-52.

- 1959. The effects of frequency and intensity of grazing on the productivity of a pasture of short-rotation ryegrass and red and white clover. N. Z. J. Agric. Res. 2: 1232-1248.

Brown, R. H. \& Blaser, R. E. 1968. Leaf area index in pasture growth. Herb. Abstr. 38: 1-9.

BRUMmer, Vегкко. 1961. Sokerijuurikkaan hehtaarisatojen ja säätekijöiden välisestä yhteydestä Suomessa. Acta Agr. Fenn. 98: 1-180.

Burg, P. F. J. van 1962. Interne stikstofsbalans, produktie van droge stof en veroudering bij gras. Versl. Landbouwk. Onderz. 68: 1-131.

Carter, J. F. \& LAw, A. G. 1948. The effect of clipping upon the vegetative development of some perennial grasses. J. Amer. Soc. Agron. 40: 1084-1091.

Davidson, J. L. \& Donald, C. M. 1958. The growth of swards of subterranean clover with particular reference to leaf area. Austr. J. Agric. Res. 9: 53-72.

Donald, C. M. 1951. Competition among pasture plants. 1. Intraspecific competition among annual pasture plants. Austr. J. Agric. Res. 2: $355-376$.

- 1956. Competition among pasture plants. Proc. $7^{\text {th }}$ Int. Grassl. Congr. Palmerston N. Z. p. $80-91$.

- 1963. Competition among crop and pasture plants. Adv. Agron. 15: 1-118.

- \& Black J. N. 1958. The significance of leaf area in pasture growth. Herb. Abstr. 28: $1-6$.

Evans, L. T. 1964. Reproduction. Grasses and grasslands. p. 126-153. Ed. Barbard, C. London. 
Frame, J. \& Hunt, I. V. 1971. The effects of cutting and grazing systems on herbage production from grass swards. J. Brit. Grassl. Soc. 26: 163-171.

GıöBEL, G. \& STEEN, E. 1960. Försök med stigande mängder kväve till mångårig betesvall. Stat. Jordbr.förs. Medd. 112: 1-58.

- 1965. Inverkan av stigande mängder kalksalpeter på betens kemiska sammansättning. Lantbr.högsk. Medd. A. 29: 1-23.

Gueguen, L. \& Fauconneau, G. 1960. Les variations des teneurs et matiéres azotées èt minérales du dactyle et de la fétuque des prés. Proc. $8^{\text {th }}$ Int. Grassl. Congr. Reading. p. $621-625$.

Наккоца, H. 1978. Nurmikasvikokeiden tuloksia. MTTK. Pohjois-Pohjanmaan koeasema. Tiedote No. 5: 1-28.

HAN, H. J., YANG, J. S., LeE, J. Y. \& PARK, K. J. 1977. [Influence of light intensity on the growth and yields of Dystaenia takesimana and two pasture species.] Res. Rep. Off. Rur. Devel. Min. Agric. Fish. 19: 123-128.

Hari, P. \& Leikola, M. 1974. Futher development of the dynamic growth model of plant height growth. Flora Bl. 163: 357-370.

Harper, J. L. \& GaIJIC, D. 1961. Experimental sudies of the mortality and plasticity of a weed. Weed Res. 1: $91-104$.

Hernrichs, D. H. \& Clark, K. W. 1961. Clipping frequency and fertilizer effects on productivity and longevity of five grasses. Can. J. Plant Sci. 41: 97-108.

Hernes, O. 1972. Forsøk med en og flere gangers slått, og høstetidspunktet for første slått. Forskn.fors. Landbr. 23: 435-445.

Hirvola, S-L., Huokuna, E. \& Rinne, S-L. 1974. The effect of heavy nitrogen fertilization on the quantity and quality of yield of meadow fescue and cocksfoot. Ann. Agric. Fenn. 13: $149-160$.

Hunt, I. V., Frame, J. \& Harkess, R. D. 1975. Interactions between first and second applications of fertilizer nitrogen and implications in efficiency of nitrogen use. J. Brit. Grassl. Soc. 30: 177-182.

HuokunA, E. 1957. Laitumien syötöstä. Maatal. ja Koetoim. 11: 82-86.

- 1960a. The effect of differential cutting on the growth of cocksfoot (Dactylis glomerata.) Proc. 8th Int. Grassl. Gongr. Reading. p. 429-432.

- 1960 b. Grazing on herbage at different grazing stages, its effect on a cocksfoot dominant ley and on milk production. Valt. Maatal.koetoim. Julk. 177: 1-44.

- 1964. The effect of frequency and height of cutting on cocksfoot swards. Ann. Agric. Fenn. 3:1-83.

- 1966. Tillering in meadow fescue swards. Proc. 10 th Int. Grassl. Gongr. Helsinki. p. $129-134$.

- 1970. Heinäsäiliörehun raaka-aineen laadunvaihtelu. Pellervo 1970, 4:200-202.

- 1971 a. Runsaan typpilannoituksen saaneiden nurmien talvehtiminen. Karjatalous 47: $334-335$.

- 1971 b. Valkuaispitoisen AIV-rehun tuottaminen heinävaltaisilla nurmilla. Karjatalous 47: $92-93$.

- 1973. Valkuaisen tuotanto nurmilla. 1. Viljelytutkimukset. Koetoim. ja Käyt. 30: 12.

- 1976. Nurmituotanto. Erkoistiedoilla kohti erkoistuvaa maataloutta: Vihreån rehun tuotanto ja käyttö. p. 8-13.

- \& HirvolA, S-L. 1974. The effect of heavy nitrogen fertilization on sward density and winter survival of grasses. Ann. Agric. Fenn. 13: 88-95.

Jones, D. I. H. \& HAYWARD, M. W. 1973. A cellulase digestion technique for predicting the dry matter digestibility of grasses. J. Sci. Fd. Agric. 24: 1419-1426.

JÄNTTI, A. \& KöYLıJ ÄRVI, J. 1964. Laidunnurmien typpilannoituskokeiden tuloksia. Viikin ja Malminkartanon kokeet 1950-56. Ann. Agric. Fenn. 3: 165-214.

Järvı, A. 1971. Heinänurmen typpilannoitus ja niittoaika. Koetoim. ja Käyt. 28: 25, 26.

- 1977. Siemenmäärän vaikutus rehukattaran satoon. Koetoim. ja Käyt. 19. 4. 1977: 15.

KAmeL, M. S. 1959. A. physiological study of shading and density effects on the growth and efficiency of solar energy conversation in some field crops. Medel. Landbouwhogesch. Wageningen 59: 1-101. 
Kelly, A. F. 1958. A comparision between two methods of measuring seasonal growth of two. strains of Dactylis glomerata when grown as spaced plants and swards. J. Brit. Grassl. Soc. 13: $99-105$.

KrvimäE, A. 1965. Timotejhöets sammansättning och smältbarhet vid framstridande skördestadier. Lantbr.högsk. Medd. A. 37:1-23.

Kvet, J., Ondok, J. P., Negas, J. \& Jarvis, P. G. 1971. Methods of growth analysis. Plant photosynthetic production. p. 343-391. Ed. Sestak, Z., Catsky, J. \& Jarvis, P. G. The Netherlands.

LAINE, T. 1954. Eri heinäkasvien suhtautumista typpilannoitukseen. Suomen Laiduntalous 27: $14-24$.

- 1955. Laidunnurmien perustamismenetelmistä ja siemenseoksista. Maatal. ja Koetoim. 9: 96-104.

- 1958. Koiranheinä savimaiden laidunkasvina. Maatal. ja Koetoim. 12: 265-276.

- 1965. Niittovälin ja sängen korkeuden vaikutus laidunnurmen satoon. Suomen Laiduntalous 37: 13-23.

- 1966. Heinäkasvien typpilannoitus. Maatal. ja Koetoim. 20:69-80.

- 1970. Typpilannoitteiden varhaislevitys ja lannoitemäärät laidunnurmilla. Koetoim. ja Käyt. 27: 16.

LAWrence, T., Warder, F. G. \& Ashford, R. 1971. Effect of stage and height of cutting on the crude protein content and crude protein yields of intermediate wheatgrass, bromegrass and reed canarygrass. Can. J. Plant Sci. 51: 41-48.

Mel., T. 1974. Growth and herbage quality of meadow fescue (Festuca pratensis Huds.) under different weather conditions. Ann. Agric. Fenn. 13: 119-124.

— \& Poutrainen, E. 1975. Säiliörehu korjattava ajoissa. Pellervo 76, 9: 14-19.

Mitchell, K. J. 1956. Growth of pasture species under controlled environment. 1. Growth at various levels of constant temperature. N. Z. J. Sci. Technol. 38: 203-216.

- \& CAlder, D. M. 1958. The light regime within pastures. N. Z. J. Agric. Res. 1: 61 -68.

Mowat, D. N., Christre, B. R. \& WrNch, J. E. 1965. The in vitro digestibility of plant parts of orchardgrass clones with advancing stages of maturity. Can. J. Plant Sci. 45: 503507.

Murtagh, G. J. \& Gross, H. D. 1966. Interception of solar radiation and growth rate of a grass sward. Proc. 10th Int. Grassl. Congr. Helsinki. p. 104-108.

NishimurA, N. \& NitTA, K. 1974. [Influence of plant density on the productivity of grassland. 2. The effect of plant density on the dry matter yield of a cocksfoot sward under two cutting frequencies.) J. Jap. Soc. Grassl. Sci. 20:45-53. (Ref. Herb. Abstr. 45: 1367.)

Norrington-Davies, J. \& Crowley, J. G. 1969. Effect of density and fertility on the competitive interactions of diploid and tetraploid ryegrasses during early growth. Ir. J. Agric. Res. 8: $359-374$.

- \& Harrifs, J. H. 1977. Competition studies in diploid and tetraploid varities of Lolium perenne. 1. The influence of density and proportion of sowing. J. Agric. Sci. Camb. 88: $405-410$.

OLofsson, S. 1962. Tillväxt och kemisk sammansättning hos några vallgräs under våren och försommaren. Stat. Jordbr.förs. Medd. 135: 123 p.

PaAtela, J. 1953. Peltonurmien perustamistavoista Suomessa. Suom. Maatal.tiet. Seur. Julk. 79: 1-81.

Pedersen, E. J. N., Moller, E. \& Mølle, K. G. 1974. The effect of cutting grequency on the yield and quality of grasses. Växtodling 28:67-73.

Pestalozzi, M. \& ØYen, J. 1977. Forsøk med sortar av fleirårig raigras 1970-76. Forskn. fors. Lantbr. 28: $661-673$.

Ронјакаlцı́, O. 1941. Nurmen perustamistavan ja nurmien kuivuudenkestävyyden vaikutuksesta niittonurmien tiheyteen ja sadon määräån. Valt. Maatal.koetoim. Julk. 114: 1-33.

Pohjonen, V. \& HARI, P. 1973. A dynamic model of crop growth rate of Italian ryegrass after cutting. Acta Agr. Scand. 23: 121-126.

PoIJĀRvI, I. 1931. Korjuuajan vaikutus heinäsadon määrään ja laatuun. Valt. Maatal.koetoim. Julk. $35: 1-93$. 
Poutiainen, E. \& Rinne, K. 1971. Korjuuasteen vaikutus säilörehun ravintoarvoon. Kehittyvä Maatalous 3: 15-28.

— \& RINne, K. 1976. Typpilannoituksen vaikutus säilörehun ravintoarvoon. Kehittyvä Maatalous 29: 14-21.

Pulli, S. 1976. Cellulase digestion technique compared with the in vitro digestibility of forages. J. Scient. Agric. Soc. Finl. 48: 187-194.

Rarninko, K. 1968. The effects of nitrogen fertilization, irrigation and number of harvestings upon leys established with various seed mixtures. Suom. Maatal.tiet. Seur. Julk. 112: 1-136.

— \& PAatela, J. 1964. Niittonurmen perustaminen ilman suojaviljaa ja käyttäen eräitä yksivuotisia nurmikasveja suojakasvina. Maatal. ja Koetoim. 18:107-113.

RAPPE, G. 1948. Några för betestillväxten karakteristiska grunddrag. Sv. Vall- och mosskulturför. Medd. 14: 585-788.

RıNNE, K. 1971. Typpilannoituksen vaikutus koiranheinä- ja nurminatanurmeen. Kehittyvä Maatalous. 5: 12-21.

- 1976. Laidunruohon kemiallinen koostumus eri typpilannoitustasoilla. J. Scient. Agric. Soc. Finl. 48: 305-316.

- 1977. Korjuuasteen vaikutus nurmen satoon ja sadon laatuun. Koetoim. ja Käyt. 12. 7. 1977: 26.

Rinne, S-L., Huokuna, E. \& Hrivola, S-L. 1976. Typpilannoituksen vaikutus ruohon laatuun. Koetoim. ja Käyt. 30.11. 1976.

SaclamtimuR, T. \& Bogdan, G. 1970. Untersuchungen über den Einfluss von Nutzungshäufigkeit und Stickstoffdüngung auf Sorten vom Deutschen Weidelgrass (Lolium perenne L.). Z. Acker- u. Pfl.bau 132: 16-35.

Salo, M-L., Nykänen, A \& Sormunen, R. 1975. Nurmikasvien koostumus, pepsiini-HClliukoisuus ja in vitro-sulavuus eri kasvuasteilla. J. Sci. Agric. Soc. Finl. 47: 480-490.

SALONEN, M. 1951. Havaintoja muutamien nurmikasvien kehityksestä kylvökesän aikana. Maatal.tiet. Aikak. 23: 135-145.

SAU, A. \& VIrRaLt, R. 1974. Increase of yield and improvement in quality of grassland herbage at grazing and frequent cutting in the Estonian SSR. Proc. 12 ${ }^{\text {th }}$ Int. Grassl. Gongr. Moscow. Utilization 2: 606-611.

ScarisBrick, D. H. \& Ivins, J. D. 1970. The effect of sowing density and cutting on competition between two pasture species growing in model populations. J. Brit. Grassl. Soc. 25: $172-179$.

STEEN, E. 1968. Inverkan av kvävegödsling på kvaliteten hos fyra vallgräs pá betestadiet. Lantbr.högsk. Medd. A. 92:1-27.

- 1972. Stigande mängder kväve till fem vallgräsarter skördade tre gånger per säsong. Lantbr.högsk. Medd. A. 176: 1-43.

Sullivan, J. T., Phillips, T. G., Loughlin, M. E. \& Spargue, V. G. 1956. Chemical composition of some forage grasses. 2. Successive cuttings during the growing season. Agron. J. 48: $11-14$.

SYrJäLÄ, L. 1973. Säilörehun ravintoarvoon ja maittavuuteen vaikuttavia tekijöitä. Karjatalous 49: $21-23$.

- 1974. Säiliörehun raaka-aineen korjuuaste. Kehittyvä Maatalous 20:27-37.

- , Suvitie, M. \& SEPPÄLÃ, J. 1978. Timoteinurmen sato, koostumus ja sulavuus kasvukauden eri aikoina. Kehittyvä Maatalous 39: 27-35.

Teitrinen, P. 1959. Apilanurmen niittoaikakokeiden tuloksia. Maatal. ja Koetoim. 13: 208217.

Terry, R. A. \& Trlley, J. M. A. 1964. The digestibility of the leaves and stems of perennial ryegrass, cocksfoot, timothy, tall fescue, lucerne and sainfoin as measured by an in vitro procedure. J. Brit. Grassl. Soc. 19:363-372.

Tномаs, N. 1974. The effect of density stress upon tillering: A physiological interpretation. Proc. 12th Int. Grassl. Gongr. Moscow. Biological and physiological aspects of the intensification of grassland utilization. p. 360-366.

Watson, D. J. 1956. Leaf growth in relation to crop yield. The growth of leaves. p. 178-191. Ed. Milthorpe, F. L., London. 
Wilman, D. 1975. Nitrogen and Italian ryegrass. 1. Growth up to 14 weeks: dry-matter yield and digestibility. J. Brit. Grassl. Soc. 30: 141-147.

WiLson, W. 1960. Influence of spatial arrangement of foliage area on light interception and pasture growth. Proc. $8^{\text {th }}$ Int. Grassl. Gongr. Reading. p. 275-279.

Winkler, H., Ohlsson, S. \& Hellberg, A. 1961. Skördetidförsök i vall kombinerande med konsevering och smältbarhetsförsök. Stat. Jordbr. förs. Medd. 118: 1-25.

Wolton, K. M. 1976. Cutting frequency and silage yields. (Summary). Agric. Fisons Techn. Inf. Autumn 1976:4-10. Ref. Herb. Abstr. 47: 1647.)

Ms received February 8, 1980.

\title{
SELOSTUS
}

\section{Viljelytoimenpiteiden ja kasvutekijödein vaikutus nurminadan kasvuun ja kehitykseen.}

\author{
Seppo Pulli \\ Helsingin yliopisto, Kasvinviljelytieteen laitos, $00710 \mathrm{Helsinki} 71$.
}

Helsingin yliopiston Kasvinviljelytieteen laitoksella tutkittiin vuosina $1975-78$ niittojen, $\mathrm{N}$-lannoituksen ja kasvutiheyden vaikutusta nurminadan sadonmuodostukseen sekä kasvun ja kehityksen suhdetta kasvutekijöihin kasvukauden eri ajankohtina. Tutkimuksista voidaan vetää seuraavat johtopäätökset:

Kylvövuoden kevätkasvun tärkeimmät LAI:ä ja pituuskasvua selittävät muuttujat olivat kasvuajan lämpösumma ja säteilysumma. Kylvövuoden syyskasvun LAI ja pituus korreloivat heikosti kasvupäiviin ja lämpösummaan. Kylvövuoden loppukesä pituuskasvuun N-lannoitus vaikutti vasta, kun lämpötilasumma oli saavuttanut arvon $500^{\circ} \mathrm{C}$.

Erot kylvömäärien välisissä kasvutiheyksissä hävisivät kuivissa olosuhteissa ankaran kilpailun vallitessa jo kahdeksan viikon kuluttua kylvöstä. Kuitenkin kylvövuonna on mahdollista kohottaa satotasoa lisäämällä kasvutiheyttä.

Kylvövuoden jälkeen nurmen kevätkasvussa tärkeimmät sadonmuodostusta selittävät muuttujat olivat kasvuaika ja kasvuajan lämpötilasumma ja säteilysumma. Keskikesällä ja syyskesällä parhaiten nurmen kasvua selittivät kasvuajan sademäärä, sadolle annettu N-lannotus sekä viikon aikana ennen edellistä niittoa saatu sade.

Kevätkasvussa lämpösummalla $750^{\circ} \mathrm{C}$ saavutettiin satotaso 6 tn ka. ha-1. Kevätsadon laatuominaisuudet olivat: ka-pitoisuus $30 \%$, rv-pitoisuus $10 \%$ ja ka-sellulaasisulavuus $50 \%$.

Kesäkasvussa lämpötilasummalla $700^{\circ} \mathrm{C}$ saavutettiin satotaso 4 tn ka. ha ${ }^{-1}$. Kesäsadon ıatuominaisuudet olivat: ka-pitoisuus $22 \%$, rv-pitoisuus $17.5 \%$ ja ka-sellulaasisulavuus $55 \%$. Syyskasvussa lämpötilasummalla $1200^{\circ} \mathrm{C}$ saavutettiin kuiva-ainesato 3.5 tn $\mathrm{ha}^{-1}$. Syyssadon laatuominaisuudet olivat: ka-pitoisuus $29 \%$, rv-pitoisuus $12 \%$ ja ka-sellulaasisulavuus $50 \%$.

Keski- ja syyskesällä nurmen kehitys oli huomattavasti kevätkasvua hitaampi. Tällöin myős sadon laatu pysyi pitkään tasaisena, sillä ka-pitoisuuden kohoaminen ja rv-pitoisuuden aleneminen olivat vähäisiä. Kevätkasvussa kuiva-ainepitoisuuden nousu ja raakavalkuaispitoisuuden lasku olivat voimakkaimpia lämpösumma-alueella $150-300^{\circ} \mathrm{C}$. Sellulaasisulavuuden lasku oli voimakkain lämpösumma-alueella $250-650^{\circ} \mathrm{C}$.

Kuiva-ainesadon ja LAI:n välillä vallitsi koko kasvukauden erittäin merkitsevä korrelaatio, Kevätkasvussa LAI:n maksimi saavutettiin arvolla 8.5, joka edustaa lämpösummaa $550^{\circ} \mathrm{C}$. Kesăkasvun ja syyskasvun LAI:-arvot 7.5 edustivat lämpösummia $700^{\circ} \mathrm{C}$ ja $1200^{\circ} \mathrm{C}$. Kevät-, kesä- ja syyskasvussa yhdellä LAI-yksikön lisäyksellä saavutettiin lisäkasvut 715 , 500 ja $315 \mathrm{~kg} \mathrm{ka}$. ha-1. Kevät- ja kesäsadon pituudet olivat 85 ja $60 \mathrm{~cm}$. Pituuskasvueroista johtuen samalla LAI-arvolla saadaan syksyä kohti yhä pienempi ka-sato. 
Niittojen lukumäärän lisäăminen merkitsee niittoa ja kasvukautta kohti pienempää satotasoa, mutta sadon laadun huomattavaa paranemista. Niittojen lukumäärän lisääminen kahdesta

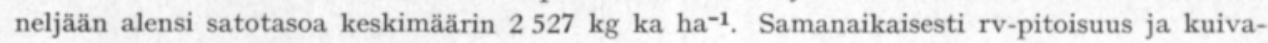
aineen sellulaasisulavuus paranivat keskimäärin 4.8 ja $13.3 \%$-yksikköä.

Typpilannoituksen lisääminen $130 \mathrm{~kg}$ :stä $260 \mathrm{~kg}$ :aan hehtaarilla kohotti kuiva-ainesatoa $1110 \mathrm{~kg} \mathrm{ha}^{-1}$. Sama typpilannoituksen lisäys nosti raakavalkuaissatoa $485 \mathrm{~kg}$ sekä sadon raakavalkuaispitoisuutta ja sellulaasisulavuutta 4.2 ja $1.4 \%$-yksikköä.

Kasvutiheyden vaikutus nurmen sadonmuodostukseen oli sitä merkittävämpi mitä useammin niitettiin.

Kylvövuoden suurin ka-sato saavutettiin kylvötiheydellä 60 kg ha-1. Kylvõvuotta seuraavana kasvukautena suurimpaan satoon 2- ja 3-niittosysteemeissä tarvittiin siemenmäärä 15 $\mathrm{kg} \mathrm{ha}^{-1}$ ja 4-niittosysteemissä $30 \mathrm{~kg} \mathrm{ha}^{-1}$. Kolmantena kasvukautena kuiva-ainesadon maksimi saavutettiin kaikissa niittosysteemeissä kylvömäärällä $15 \mathrm{~kg} \mathrm{ha}^{-1}$. Maksimisatotasoon tarvittiin suurempi kasvutiheys, jos N-lannoitusta ja niittokertoja lisättiin. Sadon laatuun kylvötiheydellä oli kylvövuotta lukuunottamatta erittäin vähäinen merkitys. Jälkisadoissa neljäntenä kasvukautena ei kylvötiheyksillä ollut tilastollisia eroja.

Kylvövuoden syyskasvulle $100 \mathrm{~kg} \mathrm{~N} \mathrm{ha}^{-1}$ ja 2-niittosysteemissä $130 \mathrm{~kg} \mathrm{~N} \mathrm{ha}^{-1} /$ niitto olivat kasvustoa liiaksi stressaavia. Nurmen tuottokyvyn säilymisen sekä nurmen määrän ja laadun kannalta parhaimmaksi viljelyteknilliseksi vaihtoehdoksi saatiin menetelmä, jossa nurminatanurmi perustettiin kylvömäärällä $30 \mathrm{~kg} \mathrm{ha}^{-1}$, niitettiin $3-4$ kertaa kasvukaudessa ja lannoitettiin $260 \mathrm{~kg} \mathrm{ha}^{-1}$. 